\title{
Motines de España y proceso contra los jesuitas
}

\author{
La "Pesquisa reservada" de 1766
}

\section{Los vacios documentales}

Los motines españoles de 1766 y la expulsión de los jesuitas (fraguada en el mismo año aunque se ejecutase al siguiente) constituyen sin duda alguna dos de los momentos más interesantes del antiguo régimen español; con protagonistas contrarios se llegó a resultados coincidentes, y, de cualquier forma, se presenció un auténtico encuentro, clamoroso o callado, de fuerzas antagónicas. Ambos sucesos, con todo su amplio cortejo de implicaciones no sólo políticas, sino sociales, económicas, religiosas y culturales, han llamado -no podía ser menos- poderosamente la atención de los historiadores, desde el testigo presencial de excepción Fernán Núñez ${ }^{1}$, pasando por la historia polémica decimonónica, hasta la llegada al momento actual, en que se asiste a un retorno al tema, aunque sea por motivos e ideologías dispares.

Sin embargo, los dos problemas se hallan en un indisimuiable punto muerto, a causa de que las fuentes apenas se han desbrozado más allá de lo que investigara Danvila ${ }^{2}$ y por la desproporción que existe entre las actuales interpretaciones y el escaso respaldo de la realidad documental.

En este sentido, las visiones tópicäs de antaño se quebraron

1. Fernan Nuñez, Conde de, Vida de Carlos III, Madrid, 1898, T. I, p. 194 ss.

2. M. Danvila y Collado, Reinado de Carlos III, t. II (en gran parte dedicado a los motines de 1766) y T. III (dedicado íntegramente a la expulsión de los jesuitas), Madrid, 1894. 
con el ensayo sugestivo de Rodriguez Casado ${ }^{3}$, al intuir -sobre textos de segunda mano- las manipulaciones que operaron en la "conjuración" aristocrática y el papel de "chivo expiatorio" que jugó la Compañía de Jesús en su presentación como muro contra la linea reformista. Sus tesis se han visto contestadas por quienes insisten en el carácter espontáneo de los motines, como Navarro Latorre ${ }^{4} \mathrm{y}$, por motivaciones muy distantes, Pierre Vilar. Este último, en un trabajo tan editado y pletórico de hipótesis como escaso en respaldo documental, ha simplificado todo el problema de los motines: partiendo del modelo posterior de la "guerra de las harinas" prestado por Francia, todo se resuelve magníficamente en el resultado de una crisis natural de subsistencias cristalizada en el omnipresente enfrentamiento de clases ${ }^{5}$. Las correcciones de Laura Rodríguez, sobre bases documentales más amplias, revelan, al menos, que las cosas no pueden considerarse con tan admirable sencillez maniquea ${ }^{6}$.

Historiadores menos dependientes de esquemas férreos, más abiertos a la sorpresa de documentación multiforme, están realizando esfuerzos para enderezar la inteligencia de los polémicos y trascendentales sucesos desde nuevas hipótesis de trabajo. Así Corona Baratech comprueba, con buenos argumentos, cómo no es posible una visión lineal, clasista ni puramente económica; hay que saber rastrear también -y el citado historiador lo hace- en otras motivaciones ideológicas; no quedarse sólo en el análisis de las estructuras, prescindiendo del momento en que se conjuran intereses y resentimientos que fuerzan el choque violento, cuyas consecuencias se conocen bien y cuya dinámica no acaba de alumbrarse, pero que tiene que encuadrarse en movimientos más largos de franca o soterrada oposición al absolutismo, ahora coincidente con los portavoces de las reformas que afectan a diversos sectores privile-

3. V. Rodríguez CASAdo, aunque haya matizado su concepto de revolución burguesa, en cuanto a los sucesos aludidos mantiene las mismas tesis en: "La Revolución burguesa del siglo XVIII español", en Arbor 18 (1951) 5-30; "Política interior de Carlos III", en Simancas I (1950) y en La política y los politicos del reinado de Carlos III, Madrid, 1962.

4. J. NAVARRo LATORRE, Hace doscientos años. Estado actual de los problemas históricos del "motín de Esquilache", Madrid, 1966.

5. Edic. castellana en "El motín de Esquilache y las crisis del antiguo régimen", en Revista de Occidente, Núm. 107 (febrero 1972) 199-249. 
giados, por lo que a los motines se refiere ${ }^{7}$. $Y$ en cuanto a la expulsión, dentro de estas mismas constantes, se está ampliando el campo visua! por las aportaciones de Olaechea y su intento de penetrar en la entraña del extraño "Partido aragonés" , y los estudios de Ferer Benimeli, al deshacer el mito del cómodo recurso a la masonería, que le vino tan bien a Eguía - como representante de una corriente universalizada - para alumbrar el misterio del destemplado extrañamiento de la Compañia 9 .

A pesar de todo, y a la hora de analizar los motines y la expulsión, el historiador honesto se encontró siempre ante un valladar insa'vable: el vacío documental de los momentos decisivos. Se dio por perdida la investigación secretísima que se llevó a cabo desde las alturas oficiales y que, partiendo del deseo de dar con los "motores del tumulto", abocó al decreto de la expulsión radical de los jesuitas por su Majestad Católica, tras un Consejo Extraordinario llevado también en el mayor de los secretos por una sala especial montada al efecto. la "Pesquisa reservada", el "Consejo Extraordina-

6. L. Rodríguez, "El motín de Madrid", en Revista de Occidente, Núm. 121 (Ab il 1973) 24-49; "Los motines de 1763 en provincias", ibid., n. 122 (mayo 1973) 183-207.

7. C. E. CoRonA es el historiador actual que ha sabido integrar estas conmociones dentro de la dinámica más general y con una visión más histórica y menos polémica. Cfr. planteado ya el problema en Revolución y reacción en el reinado de Carlos IV, Madrid, 1957; "El motín de Zaragoza del 6 de abril de 1766", en Zaragoza 14 (1961) 197-228: "El poder real y los motines de 1766", en Homenaje al Doctor Canellas, Zaragoza, 1969, 259-277; "Sobre el Conde de Aranda y sobre la expulsión de los jesuitas", en Homenaje al Dr. D. Juan Reglà Campistol, II, Valencia, 1975, 79-106; "Sobre el tránsito del absolutismo al liberalismo", en Cuadernos de Investigación 2 (1975) 63-82.

8. R. OLALCHEA, El conde de Aranda y el "partido aragonés", Zaragoza 1969. También ha estudiado ambas realidades en el T. I de su tesis doctoral Las relaciones hispano-romanas en la segunda mitad del siglo XVIII. La Agencia de Preces, Zaragoza, 1965, así como en otros trabajos que citaremos oportunamente.

9. C. Egứa trasmite la tesis común del influjo de la masonería en am.bas operaciones, $y$ en realidad no hace sino confirmar tesis de Vicente de la Fuente, por ejemplo. Cfr. su Los jesuitas y el motín de Esquilache, Madrid, 1947, con fuertes tonos polémicos y también con buena documentación directa. Ha destrozado materialmente estos tópicos acerca de las fuerzas de la masonería española en aquellos tiempos J. A. Ferrer BenIMELI en un cúmulo de trabajos convincentes y llenos de novedad. Cfr. fundamentalmente Bibliografia de la Masoneria. Introducción históricocritica, Zaragoza, 1974; Sucedió en Graus hace doscientos años. Notas sobre Aranda y la expulsión de los jesuitas, Zaragoza, 1968; "La expulsión de los jesuitas por Carlos III" en Historia y vida (mayo 1973) 30-49; La masonería española en el siglo XVIII, Madrid, 1974. Olaechea y Ferrer Benimeli, junto con el director del equipo, Corona, están llevando a cabo investigaciones que esperamos sean decisivas en torno a estos problemas. 
rio", se convirtieron en magníficas piezas vedadas, imposibles de cobrar para la investigación, y celadoras inasequibles del misterio difícilmente desvelable sin tales instrumentos decisivos.

Pues bien, el motivo de este trabajo, y jugando quizá más a eruditos que a historiadores, radica en ofrecer el contenido de álgunas de estas piezas recobradas, y, concretamente en esta ocasión, de parte - la única con que hemos dado en nuestra investigación- de la famosa desconocida "Pesquisa secreta".

\section{La "Pesquisa reservada"}

La actividad febril investigadora que se llevó a cabo desde abril a diciembre de aquel agitado 1766 estuvo provocada por el deseo inicial de dar con los responsables del motín o de los motines primaverales y por el cúmulo de sátiras, invectivas y acciones aisladas que los siguieron. Este "dossier" constituye una referencia excepcional para percibir los cambios que se registran en la visión oficial de los sucesos, hasta el punto de que al final, muy posiblemente, se llegó a resultados imprevistos cuando la "Pesquisa". se ordenó por Carlos III.

La versión apresurada y directa de Aranda, dos días antes de posesionarse de la presidencia del Consejo de Castilla, alude ya a motores y capataces de los tumultos madrileños, a "los impulsores de otra clase que se descubra haber preparado las primeras acciones populares para complemento de sus ideas"; sin embargo prevalece la convicción de que la plebe ha reaccionado a impulsos de la xenofobia contra Esquilache, agudizada por las medidas odiosas, en la primera fase del motín, y por el recelo y temor ante posibles represiones en la segunda. La relación no puede ser más tranquilizadora, si bien no se disimula el contagio de otras ciudades ante la agitación persistente ${ }^{10}$.

Fue la conexión de los alborotos con las "clases peligrosas", con los marginados, la que forzó medidas inmediatas de recogida de vagos, pobres, malentretenidos ${ }^{11}$; la que hizo renovar viejas prohi1009.

10. Aranda a Roda, Madrid, 9 abril 1766, AGS, Gracia y Justicia, Leg.

11. Exhaustivamente $-\mathrm{y}$ cuantitativamente- estudiado por Rosa PÉREZ ES:ÉVEZ, El problema de los vagos en la España del siglo XVIII, Madrid, 1976. 
biciones contra clérigos vagantes en Madrid, contra forasteros y solicitantes que pululan por la Corte y a los que se cree comprometidos en las inquietudes y responsables de la producción panfletaria que se propaga con celeridad de mano en mano ${ }^{12}$ y a la que se concedió importancia extraordinaria como resorte de la oposición clandestina. Fue precisamente este recurso de los descontentos lo que forzó providencias que incautaron las imprentas clericales, lo que desencadenó acciones policiales contra los murmuradores del gobierno, lo que constituyó la tupida red de espionaje para identificar a los autores y propagadores de papelones anónimos ${ }^{13}$, y 10 que, en fin, puso en marcha la gigantesca "Pesquisa reservada" que cubriría prácticamente todas las diócesis españolas y haría desfilar ante tribunales constituidos al efecto a centenares de delatores; amparados en el sigilo más riguroso, de raigambre inquisitorial, y ante los cuales el reo no encontraría resquicio posible para la autodefensa.

La historia externa de la "pesquisa" ha sido trazada por cuantos $-\mathrm{y}$ han sido muchos como para citarlos - se han ocupado de los motines y de la expulsión de los jesuitas. Ello nos exime de reiteraciones, pero no excusa la observación de algunos detalles significativos.

En principio se percibe una evolución sensible desde el primer real decreto que la instituye, al mes de explotados los tumultos, hasta que en septiembre del mismo 1766 se ultiman los detalles y se recogen las delaciones postreras que darán cuerpo al Dictamen fiscal del día de nochevieja. Es éste -el Dictamen fiscal de fin de año- la pieza clave de todo el proceso, más decisiva aún que los Consejos extraordinarios que precedieron a la operación masiva del inminente extrañamiento y que, en todo caso, no hicieron sino sancionar las conclusiones de Campomanes, conforme a la tónica

12. Cfr. la nutrida correspondencia entre Roda y Aranda, como responsables de los organismos competentes en la materia (Consejo de Castilla, Secretaría de Gracia y Justicia) de estos meses de abril y mayo 1766 a este repec'́o en AGS, Gracia y Justicia, leg. 1009. La legislación está recogida en Noviss. Recop., Ley 6, tít. 15, lib. 1; Ley 8, tít. 8, lib. 1; y ha sido analizada ya por C. Corona, Sobre el conde de Aranda, p. 82-83.

13. AGS, Gracia y Justicia, Leg. 1009 contiene los intentos policiales de control, relación de tabernas y casas de huéspedes, etc. En estos quehaceres Roda y Aranda encontraron buena ayuda en la eficacia de Olavide. Cfr. M. Defourneaux, Pablo de olavide ou "l'afrancesado" (1725-1803), Paris, 1959. 
normal de los componentes de la Sala, plenamente conectados con su pensar y con su hacer ${ }^{14}$.

El propio - y aludido- decreto real (21 abril 1766), que deja ver cómo ya se ha registrado el rápido trasvase de sospechosos ("esta cizaña - los papeles sediciosos- no dimanan del pueblo de Madrid") de la plebe a los "privilegiados", evidencia también la voluntad del monarca de que sea "mi fiscal D. Pedro Rodríguez Campomanes" el factotum de la delicada investigación ${ }^{15}$. Aranda, el flamante presidente, no debió hacer más, al parecer -y cuando lo hizo- que presidir el Consejo, firmar los documentos, asentir a lo que le presenta hecho el tándem Campomanes-Roda (secretario, el último, de Gracia y Justicia), hacia los cuales no se debió manifestar demasiado entusiasmado, dando pie con su actitud a reforzar la sospecha de si el llamado "Partido aragonés" existió realmente como fuerza homogénea de actuación en los elementos que se le suelen adscribir por el simple origen geográfico ${ }^{16}$.

Es ya Campomanes el que mueve los hilos de la trama cuando al mes y medio fuerza la creación de una sala especial, a espaldas del Consejo de Castilla, integrada por personas hostiles a la Compañía y adictas a la ideología del fiscal. La selección aparece como exigencia imprescindible para garantizar el solemnísimo secreto y para "tratarse con la debida expedición esta pesquisa", misterio y prisas imposibles de conciliar con el heterogéneo cuerpo del pleno (compuesto además en su gran mayoría por suaristas y "terciarios"

14. Este Dictamen fiscal del 31 de de diciembre de Campomanes es la pieza fundamental y desconocida de todo el proceso. En ella se recoge el material proporcionado por las pesquisas anteriores en toda España y se formula el pedimento de expulsión al que se avendría Carlos III. El documento excepcional se conserva en AC (Archivo de Campomanes, Fundación Universitaria Española) 45-4. Será publicado por la referiđa Fundación próximamente y en edición preparada por Jorge Cejudo y Teófanes Egido.

15. "Al fin de que esta averiguación y pesquisa se ejecute con parte y orden legitima, se comunicarán todas las diligencias que se vayan actuando y cualesquier documentos reservados a mi Fiscal, D. Pedro Rodríguez Campomanes, a quien en calidad de tal mando proceda en este particular con la eficacia que el caso pide. Reservo declarar a su tiempo el modo de verse por el Consejo este negocio, de cuya breve substanciación cuidaréis vos, el Presidente, y de que se trate con la reserva que piđe, dándome noticia de lo que ocurra y se adelante". Carlos III a Aranda, Aranjuez, 21 abril 1766, AGS, Gracia y Justicia, Leg. 1009, 7.

16. No tardaron en surgir diferencias entre Aranda y Roda-Campomanes, siendo éstas las causas fundamentales de su alejamiento posterior. Cfr. R. Olaechea, El Conde de Aranda y el "partido aragonés", y C. CoRona, "Sobre el conde de Aranda", p. 89-ss. 
jesuitas) ${ }^{17}$. En las razones que abonan la creación de la Junta no se habla ya de "privilegiados" sin más; las delaciones que fluyen de todas partes confirman la convicción fiscal de que "los seductores de la plebe" han sido "personas eclesiásticas" ${ }^{18}$.

El material recibido permite a Campomanes adelantar en septiembre ciertas conclusiones que centran las responsabilidades del motín y de los sucesos posteriores en "un cuerpo peligroso". No es necesario que se hable expresamente de los jesuitas, ni el lenguaje es tan críptico como para no percibir la intención de convertirlos en víctimas del proceso en calidad de "agentes únicos de los bullicios pasados y de los que siempre pueden recelarse mientras este cuerpo esté incorporado a la masa general del Estado y de la nación". En consecuencia el fiscal solicita vía libre para actuar, para aplicar la legislación medieval sin trabas de ninguna clase contra los reos de Estado, en un programa bien pensado y tendente a aislar a la Compañía ${ }^{19}$ del resto de las religiones (presentadas desde una óptica angelical ahora). Buen conocedor de rivalidades clericales, Campomanes juega una baza decisiva que le facilitará todos los justificantes deseados. Naturalmente, el monarca se pliega a todo, $y$, armado de licencias, de permisos de la nunciatura, de garantías para el mayor sigilo de los testigos, se lanza el fiscal a la última ofensiva que aspira a "las providencias que convenga tomar para la radical extirpación de mis dominios de todo pábulo o semilla en lo venidero de semejantes desacatos, atentados y escándalos, ofensivos a la religión misma y de la obediencia a la soberanía y seguridad de las personas públicas, apartando el abuso que sobre esto se experimenta" ${ }^{20}$, como dice el rey al Consejo Extraordinario que tiene que deliberar sobre las conclusiones de Campomanes en un secreto cuya violación se considerará delito de Estado.

17. El P. Lesmes Frías publicó, mutilada, una relación de los componentes del Consejo y la orientación de su adscripción jesuita o tomista. Rodríguez Casado, La politica y los políticos, 191-195, dedujo las consecuencias que esto tuvo en el proceso de los jesuitas, y R. Olaechea, al tanto del documento íntegro, lo ha encuadrado en su contexto general, del cual se desprende que la alta administración estaba integrada por el $80 \%$ de Colegiales Mayores, con todo lo que ello entraña en cuanto a connotaciones políticas y económicas. Cfr. Las relaciones hispano-romanas, I, 315 ss. (La relación de Frías, en Razón y Fe, 29 (1911) 168-169.

18. Consulta 8 junio 1766. AGS, Gracia y Justicia, Leg. 1009, 12.

19. Consejo Extraordinario, 11 septiembre 1766, ibid., 179-180.

20. Carlos III a Aranda, El Escorial, 31 octubre 1766, ibid., 16. 
Entre los motines y la decisión precoz del extrañamiento han sucedido muchas cosas que, junto a determinantes de mayor alcance ("expectativas sobre temporalidades", asuntos del Paraguay, asociación jesuitas-colegios mayores-aristocracia, poder educacional y prestigo jesuíticos, clima europeo preñado de hostilidades concepciones dispares del poder y función monárquicos, etc), han sentenciado definitivamente la desventura de la Compañía. Estos episodios, que actúan como desencadenantes ocasionales de su expulsión, pueden verse en el alejamiento de Ensenada, su amigo; la desaparición de la reina madre, Isabel de Farnesio, vieja ya, pero que influye en el monarca y para los dardos antijesuíticos de los gobernantes. Curiosamente, nada más morir (11 julio 1766) es cuando todo toma un rumbo rectilíneo contra la Compañia ${ }^{21}$. Nada importa que encartados bien conocidos como Gándara, Hermoso, Valdeflores, no evacuasen nada en concreto contra los reos presuntos; desde Nápoles, Tanucci, entre maníaco y preocupante, desencadena la tempestad de cartas incontables, capaces de afianzar - si hubiera sido necesario - la fuerza de Campomanes y del confidente Ro$\mathrm{da}^{22}$ y de obsesionar al monarca con el espectro del enemigo, tremendo-y poco necesitaba Carlos III, asustado, y aún no repuesto en su lejanía de Aranjuez del impacto producido por los motines ${ }^{23}$.

Para justificar legalmente el programa concreto -quizá desbordado en su última fase- era preciso contar con todas las for-

21. Está fuera de dudas el papel real de parachoques que desempeñó Isabel de Farnesio. Cfr. las cartas privadas de jesuitas que así lo confirman en AGS, Gracia y Justicia, Leg. 777, 184. El Provincial jesuita, P. Nectuoso, escribia antes, en 1765 -obsérvese el clima anterior a los motinesal General Ricci: "En España tiene la Compañía muchos enemigos y muy prevenidos a contradecirla; éstos serán ayudados con el favor de un ministro (Roda) que está para venir desde Roma a ejercer un empleo muy acomodado para expulsar a la Compañia. Los jesuitas españoles no ignoran esto, pero piensan que no deben temer mientras viva la reina madre". En M. F. MIGuÉLEz, Jansenismo y Regalismo en España (Datos para la historia), Valladolid, 1895. p. 304. Más datos en M. Danvila, El reinado de Carlos III, II, 615-616 y en C. Conona, "Sobre el conde de Aranda", 90-91.

22. Han estudiado esta correspondencia hostil de Tanucci M. DanvILA, O. c., III, 11 ss; C. Eguía, o. c., p. 139 ss.- V. Rodríguez Casado, o. c., etc.

23. No fue el rey el único en asustarse ante la conmoción, a pesar de que así lo cree L. Rodríguez, a. c., I, 38. La documentación dice todo lo contrario, y para registrar este clima de pánico, en el que la única persona serena pareció ser Isabel de Farnesio, bastaría con releer las relaciones de aquellos momentos. Cfr., por ejemplo, cómo se expresa el marqués de San Leonardo en las cartas que por aquellos días escribía. Cfr. José CEPEDA ADÁN, "El Madrid de Carlos III en las cartas del Marqués de San Leonardo", en Anales del Instituto de Estudios Madrileños 1 (1966) 226-227. 
malidades del montaje de la "Pesquisa reservada" y secretísima, que comenzó investigando las responsabilidades de un motín y acabó con la expulsión de los jesuitas, presentados como protagonistas dei suceso y como los más enconados enemigos de la monarquía del tembioroso Carlos.

\section{Documentación recuperada.}

La búsqueda de fuentes documentales definitivas de los motines de Madrid chocó siempre con la pérdida de esta larga investigación llevada por Campomanes. Lo mismo que el texto de los últimos Consejos Extraordinarios definitivos del 21 de enero de 1767, el dossier de la "Pesquisa", a la que no se ceja de aludir en los restos de los archivos, se creyó inaccesible; deliberadamente desaparecida. Ya en 1815 el fiscal del Consejo de Castilla, Gutiérrez de la Huerta, en su dictamen -y en un ambiente político- antagónico al de su antecesor, lamenta el vacío. La queja del defensor del restablecimiento de los jesuitas en años de reacción absolutista se ha repetido por todos los investigadores, al ver fallida la esperanza de documentar de manera fehaciente los misterios de los motines, de la expulsión y su extraña, pero inevitable, interdependencia ${ }^{24}$.

El secreto se ha desvelado recientemente, al abrir a la investigación el archivo personal de Campomanes, celosamente conservado por sus herederos ${ }^{25}$. Aunque falten aún fondos por integrarse, el depósito disponible posibilita buen punto de partida ${ }^{26}$. $Y$ entre su material opulento para todo dieciochista se halla parte de la esquiva y dichosa "Pesquisa reservada" de aquel $1766^{27}$. Faltan delaciones

24. Francisco Gutiérrez de la Huerta, nacido por los días de los motines, conforme confiesa él mismo, se queja de la pérdida de esta. documentación, en el interesante Dictamen del fiscal.(...) sobre el restablecimiento de los jesuitas, Madrid, 1845, p. 6,66. Aunque editado en aquel año, fue escrito en 1815, y es un valioso documento poco conocido.

25. No hace mucho tiempo se han depositado en la Fundación Universitaria Española los fondos de Campomanes que conservaban sus herederos Carmen Dorado y Rafael Gasset. Allí los hemos consultado, y con gusto agradecemos a la citada Fundación, y en especial a su bibliotecario y $\mathrm{mi}$ amigo, Jorge Cejudo, las facilidades que siempre me han brindado para la utilización de los documentos.

26. Cfr. el material descrito en J. CeJudo LóPEz, Catálogo del archivo del conde de Campomanes (Fondos Carmen Dorado y Rafael Gasset), con prólogo interesante de Justo García Morales, Madrid, 1975.

27. Sospechamos que el resto puede encontrarse en los fondos que aún no han abierto a la investigación los otros herederos de Campomanes, a pesar de los esfuerzos que en este sentido se están realizando. 
de primera hora, aquellas realizadas por los Alcaldes de Casa y Corte en Madrid, las de Zaragoza, Cuenca y Toledo, las de Guadalajara, etc., pero las que se transmiten, permiten hacerse una idea de lo relativamente exacta - aunque tendenciosa - observación de Gutiérrez de la Huerta: "no bien se adoptaron estas medidas cuando se sembró España de espias secretos; se promovieron quejas, denuncias y testigos falsos, se abrigó a todo maldiciente de jesuitas, y cuantos empleos vacaban servían para premiar amigos y aumentar partidarios" ${ }^{28}$.

Los informes remitidos desde Cádiz, Puerto de Santa María, Sevilla, se centran en confesiones logradas sobre la difusión clandestina de impresos esparcidos por los jesuitas, en un esfuerzo comprensible y desesperado para prevenir a la opinión contra las medidas que contra ellos se habian tomado en Francia y en Portugal ${ }^{29}$. En Vizcaya se añaden las diligencias practicadas para investigar la penetración de las palabras y escritos "regicidas" del $P$. Calatayud ${ }^{30}$, y de Córdoba llega una carpeta nutrida de pronósticos, sátiras; papeles relativos al motín de Esquilache y a sus presuntos motores ${ }^{31}$. Es un material envidiable para rastrear los poderosos resortes que puede mover la Compañía en sus campañas de penetración en la opinión pública. No obstante, y de momento, prescindiremos de su análisis tentador, puesto que el propósito de estas páginas se centra en establecer la relación que este proceso contra los jesuitas establece entre los motines madrileños y la colectividad de la Compañía de Jesús.

Desafortunadamente no hemos podido dar con los papeles logrados en otros sitios y que a la fuerza tuvo que incorporar Campomanes como justificación de su dictamen. Pero, por suerte, contamos con los resultados de las pesquisas realizadas en el Principado de Cataluña, en Gerona y Barcelona en concreto, explotados también con generosidad por el fiscal ${ }^{32}$. Debieron ser éstas las últimas, las más completas y mejor montadas, y ello justifica mirarlas como modelo legítimo de lo que debió suceder en otros lugares.

28. O. c., p. 231.

29. AC $42-5 ; 43-1 ; 43-4$ bis; $43-5$.

30. AC $42-4$.

31. AC 43-7.

32. No se han recuperado aún las investigaciones realizadas por las pesquisas de Lérida y Tarragona. 


\title{
4. La comisión y los testigos
}

El mismo día 30 de septiembre de 1766 recibieron por vías oficiales el obispo de Gerona y el Oidor barcelonés Lorieri sendas comunicaciones apremiantes del presidente del Consejo de Castilla en persona:

\begin{abstract}
"Para que con la mayor reserva reciba sumaria información al tenor de los particulares que comprehende la inclusa Instrucción, firmada del Sr. Fiscal del Consejo, y acompaño copia de las Letras del Rvdo. Nuncio respecto a los regulares que convenga declaren, para que no se excusen; tomando juramento a los testigos no sólo de decir verdad, sino de guardar el más profundo secreto, pena de que serán castigados como reveladores del secreto de Estado".
\end{abstract}

La Instrucción firmada por Campomanes explicita los dos puntos concretos a que debe ceñirse el interrogatorio:

\begin{abstract}
"1." Lo primero, si en aquella ciudad y sus inmediaciones se han impreso algunas obras anónimas, relativas a los negocios de Ios jesuitas en Francia, o el Breve Apostolicum, relativo al Instituto, en latín o en castellano, y con qué licencias, tomándose aeclaración a los eclesiásticos, aunque sean regulares, en fuerza de las Letras que acompañan, y lo mismo a los seglares, haciendo reconocimiento de las imprentas, si alguna hubiere; en que resulte haberse impreso dichas obras o los Breves dirigidos a algunos obispos en España sobre la confirmación del Instituto. 2.․ Igual averiguación se hará en razón de sermones o predicciones contra el gobierno, de los jesuitas u otros cualesquiera, que puedan tener alusión a las novedades pasadas" ${ }^{33}$.
\end{abstract}

Los comisionados ponen manos a una obra en la que se juega "el orden y la tranquilidad pública", "la regia potestad", etc., etc., y a primeros de noviembre se remiten, ya cumplimentados, los expedientes a Aranda. En Lérida parece que se filtraron las noticias sobre la pesquisa, y por ello el obispo gerundense toma cuantas precauciones juzga necesarias, evitando incluso el depósito en la estafeta y haciendo acudir personalmente al administrador de correos a palacio ${ }^{34}$.

33. AC 43-3, fol. $1 \mathrm{r}$; fol. $2 \mathrm{r}-\mathrm{v}$; AC 42-6 (1), fol. 1r-ss.

34. "Se ha logrado -dice el obispo de Gerona a Aranda, 9 nov. 1766 - o a lo menos no tengo especie de que se haya traslucido cosa alguna, aunque las gentes andan con cuidado, por haber sido público aquí lo sucedido en Lérida $\mathrm{y}$ haber tenido estos PP. aviso de ahí a que aquí habría también venido o vendria Comisión; por lo que han tomado la providencia de tener a todas horas cerrada la puerta principal del Colegio $y$ el coadjutor portero de centinela". AC 42-6 (1), fol. 9r. 
Más interés tiene el análisis de los testigos para la comprensión del alcance de las acusaciones. En Gerona se interroga a 9 eclesiásticos y a 12 seglares; en Barcelona a 8 seglares y 28 eclesiásticos. En uno y otro lugar la investigación se lleva de forma deliberadamente discriminatoria: sólo se interroga a quienes previamente se conoce bien como furibundos enemigos de la Compañía, sin ofrecer ninguna oportunidad a tantos "apasionados devotos", "afectos" "terciarios", "suaristas", "confesados y confesadas", como saltan a cada paso en las deciaraciones testificales. La medida, por otra parte, es comprensible; si se trata de reservarlo todo en el más estricto secreto, en una época en que se piensa ya en la expu'sión, no se puede correr el riesgo de que los jesuitas y adictos se enteren de lo que se ventila; pero es que, además, la norma viene dictada por Campomanes, al añadir a sus intrucciones la orden de que se interrogue en Gerona al canónigo Francisco Berga y en Barcelona al capitán de Suizos Juan Abbach.

Y Juan Abbach, el canónigo Berga, junto con el Doctor Gafarot (comisionado episcopal para interrogar a los seglares gerundenses) serán los testigos principales, interdependientes, en comunicación constante entre sí, y con declaraciones tan gemelas, que es imposible descartar el acuerdo previo ${ }^{35}$. El resto de las pruebas que se acumulan gravita en torno a las evacuadas por estos personajes, coincidentes en su enemistad personal hacia los jesuitas, espiados por los testigos de excepción desde tiempos anteriores a la pesquisa.

Efectivamente, sus amplias deposiciones dejan ver el furor tomista de Berga, sus choques lejanos y próximos con algunos jesuitas que le han hecho víctima - según sus seguridades- de invectivas satíricas mordaces y de amenazas ${ }^{36}$; la rivalidad se había trocado en franca ruptura desde hacía diez años, cuando el canónigo

35. En efecto, aparece el mismo esquema y acusaciones idénticas en las evacuaciones de estos tres testigos y dependencias de ellos en los restantes, como podremos contrastar a continuación. Por ejemplo, y por no multiplicar los casos, cuando se acusa a los jesuitas de haber provocado prácticamente cuantas conmociones contra los gobiernos ha registrado la historia moderna, los tres lo apoyan en sus lecturas frecuentes "de libros españoles, italianos y franceses que tratan de estos PP". (Berga), AC 42-6 (2), fol. 29r; Gafarot en los "muchos libros franceses, italianos y latinos que he leído", AC 42-6 (3), fol 26r; y algo similar en Abbach, AC 43-3, fol $22 \mathrm{v}$.

36. Declaración del canónigo Berga, AC 4.2-6 (2), fol. 31v; $42 \mathrm{r}$. 
andaba por la Corte. Por 1766 encabeza el sector hostil del cabildo, profunda y violentamente dividido entre filo y antijesuitas ${ }^{37}$. Al canónigo y al comisionado para seglares les unen, si no lazos de amistad, actitudes comunes de resentimiento: Gafarot es víctima de la influencia que los jesuitas ejercen sobre su mujer, sobre su suegro, y en sus morosas declaraciones se percibe la tragedia de la desavenencia conyugal que han provocado los problemas de la Compañía y determinados influjos sugeridos desde el confesonario (y este conflicto familiar, estas divisiones internas, no son los únicos que aparecen a lo largo de toda la pesquisa, como muestra de cómo vivía aquella sociedad una contienda de esta índole).

$Y$ así van sucediéndose émulos de la Compañia, hábilmente seleccionados, y en un consenso de uniformidades. El grueso de las. pruebas están facilitadas por miembros enemigos del cabildo gerundense, por un mercedario, un franciscano, un dominico y seglares desafectos, quienes, sin excepción de monta, hablan de datos trasmitidos por el canónigo Berga. En Barcelona, la estadística testifical es significativa: declaran $-y$ ya se sabe que siempre en contra- 1 estudiante de moral, 2 capellanes militares y otro honorario del Rey, 1 médico, el impresor Piferrer, Jerónimo Capmany, 1 consejero de S. M., 1 fiscal de la Audiencia y 8 sacerdotes seculares, tomistas acérrimos; entre los frailes, 1 benedictino (que nunca quiso celebrar en iglesias jesuitas por miedo a no estar las aras debidamente consagradas), 1 mercedario, 1 miembro de la Congregación de la Misión, 4 carmelitas calzados y nada menos que 7 dominicos.

Es decir, todos resentidos de una forma $u$ otra con la Compañía, en un tiempo en que las rivalidades de escuela, como veremos, trascienden de posturas y dimensiones meramente académicas ${ }^{38}$.

37. Por la inacabable declaración de Berga y de otros canónigos gerundeses se desprende con toda evidencia cómo el cabildo, en efecto, refleja la división general de España en este asunto. De forma constante aparecen los nombres de los miembros del Cabildo "apasionados" a los jesuitas y de sus enemigos; de éstos van desfilando todos por la "Pesquisa", de los elementos amigos no se cita a ninguno a declarar.

38. Es extraño que en Barcelona no se cite a los Carmelitas Descalzos, reconocidísimos enemigos de los jesuitas, afectados también por la causa del Venerable Palafox, comentarista de las cartas de Santa Teresa de Jesús. Precisamente algunos descalzos facilitaron a los émulos de la Compañía ejemplares de este epistolario en que la Santa ataca con cierta dureza a los "teatinos". Cfr. Vicente de LA Fuente, "Preliminares" al Epistolario de la Santa en B.A.E. 55, Madrid, edic. 1952, p. XXVII. 


\section{Las acusaciones}

La "Pesquisa" tiene dos objetivos fundamentales: la averiguación de las responsabilidades jesuíticas en la difusión de impresos pontificios, episcopales foráneos y favorables a su causa, y su posible participación en los tumultos de Madrid. Pero todo envuelto en una serie de acusaciones que conspiran al mismo fin: presentar el cuerpo de la Compañía como enemigo colectivo de la monarquía de Carlos III y como el mayor peligro para la propia institución monárquica.

En cuanto a la difusión de impresos projesuíticos falla la tentativa de localizar su impresión en el Principado. Narciso Oliva, impresor gerundense, nada puede probar al respecto ${ }^{39}$, y Piferrer, muy explícito y convencido en su primera declaración de que Breves, Apologías y Catecismos fueron impresos en Cataluña, no tarda en desdecirse en las siguientes compariciones, al confesar "que no se atreve a asegurar el lugar de su impresión, porque está hecha con tal picardía, que no conoce la marca del papel" "40. De todas formas, salta a la vista que los jesuitas explotan un dispositivo formidable de reparto que parte de las porterías de los colegios y llega a espacios extraurbanos, cubiertos por la red densa de sus adictos incondicionales, muchos y poderosos.

Al margen de ello $-y$ pese, repetimos, al interés de este capítulo - nos interesa más directamente explorar los datos que puedan clarificar - u oscurecer- los móviles y detalles referentes a los motines y al papel que la Compañía puede desempeñar en el juego de la oposición al gobierno.

\section{1.- Los jesuitas, únicos autores de los motines}

Además del interés por la difusión de la literatura de defensa, la fuerza del interrogatorio se centra primordialmente en averiguar si el testigo de turno puede evacuar algún dato que comprometa la participación jesuítica en los motines madrileños ${ }^{41}$. Naturalmente,

39. AC 42-6 (3), fols. $9 \mathrm{r}-\mathrm{v} ; 24 \mathrm{r}-25 \mathrm{v}$.

40. AC $43-3$, fols. $75 \mathrm{r}-76 \mathrm{r} ; 99 \mathrm{v}-100 \mathrm{r} ; 115 \mathrm{r}-\mathrm{v}$.

41. En el interrogatorio barcelonés, el comisionado Lorieri plantea el cuestionario de forma que los deponentes tienen que atenerse a la siguiente sugerente pregunta: "2.0: Si saben que los jesuitas han hablado y hablan contra el gobierno, y si en los sermones que han predicado se han explicado quejosos de él $\mathrm{y}$ del ministerio, y si les han oído algunas 
y salvo un par de excepciones, la respuesta no puede ser más contundente. El canónigo Berga - fuente directa o indirecta de casi todas las testificaciones- en cuanto, a los diez días de sucedido, tuvo noticia del motín, instintivamente lo asoció a complicidades o eficiencias jesuitas: "concebí desde luego que leí y reflexioné la citada carta, que muy bien habrian podido ser los jesuitas los autores y actores clandestinos de aquel motín" ${ }^{42}$.

Lo que en él -y en su dependiente Gafarot- es un movimiento instintivo de suspicacia se torna en seguridades incondicionadas en el resto; algunos transmiten ser voz común que "el motín había sido movido por los jesuitas" ${ }^{43}$; otros, por lo oído y observado en los afectos a la Compañía, "tienen formado juicio de que los jesuitas han sido los autores no sólo del motín de Madrid, sino de otros muchos" "4. Los conceptos vertidos en Gerona se repiten en Barcelona: "también he oído decir públicamente que los que habían causado y dispuesto el tumulto de Madrid fueron los jesuitas"; "que tiene por cierto que éstos fueron los motores del tumulto de Madrid o los que cooperaron a él" ${ }^{45}$.

El argumento decisivo de la voz y fama común indica el clima de la opinión pública; mejor dicho, de la opinión del sector comprometido, el único que desfila por la "Pesquisa", y precisamente las ausencias de confrontaciones imposibilitan deducciones seguras. En este sentido, y para su tratamiento metodológico, resulta bastante indicador el testimonio de otro canónigo, nada afecto a la Com-

conversaciones o predicciones que puedan tener alusión con las novedades pasadas y con lo ocurrido en la Corte el presente año". AC 43-3, fol. 4. V.

42. AC 42-6 (2), fol. 29v. También Gafarot, en declaración de factura idéntica a la anterior, en cuanto se enteró de los sucesos, "al instante interiormente sospeché no hubiese sido fomentado por los padres jesuitas". AC 42-6 (3), fol. $26 \mathrm{r}$.

43. Gerona, P. Jerónimo Puig, OP, AC 42-6 (2), fol. 10r; Joseph Feliú y Arenas, AC 42-6 (3), fol. 8v.

4.4. Mariano Sadurní (canónigo de Gerona), AC 42-6 (2), fol. 15v; Narciso Farró (beneficiado): "Y que asimismo conjetura que pudieron tener mucha parte en el motín de Madrid, por persuasión de que a nadie como a ellos pudiera traer interés la revolución del Reyno", fol. 19r; Joseph del Valle, 42-6 (3), fol. 13v; Antonio Aloy, ibid., fol. 15r.

45. P. Angel Molas, OC, AC 43-3, fol. 70v; P. Isidoro Riera, OsB, ibid., fol. 78v; P. Domingo Fuster, OP, ibid., fol. 80v; P. Angel Clapers, OC, fol. 105r. El Capellán de artilleria, Esteban Patau, "no duda que los jesuitas fueron los que movieron el alboroto de Madrid, pues, a más de haberlo oído decir públicamente y ser ésta la voz común y fama en esta ciudad...", ibid., fol. 82 r. 
pañia, y que puede desvelar en parte la fuente real de esta corriente en la sensibilizada Gerona:

"No tiene noticia que en esta ciudad se haya predicado sermón alguno injurioso a S.R.M., ministros o gobierno, ni de los je suitas ni de otro alguno; y que tampoco ha oído hablar de predicciones algunas, sino sólo al canónigo Berga, quien le dijo en una ocasión que un jesuita habia interpretado que un fenómeno que se vio en esta ciudad este año podía significar la muerte del rey" $t 6$

Los historiadores actuales, empeñados en llegar a las causas complejas y a los responsables oscuros de los sucesos críticos de 1766, pueden contrastar la sencillez con que en la "Pesquisa reservada" se resuelven todos los misterios de los motines a los pocos meses de encendidos y en escenarios alejados. Las afirmaciones -deducciones y sospechas las más de las veces- se basan en argumentos que, en ocasiones, no trascienden de lo pintoresco, y que, en otras circunstancias, tienen correspondencia con tantas relaciones coetáneas como corrieron por Madrid, pero aplicadas en este espacio catalán a los jesuitas.

Así, por ejemplo, aquellos personajes distinguidos, con medias de seda, que abonaron a los escasos perjudicados sus gastos y desperfectos, y que en las relaciones anónimas se identifican genéricamente con algunos aristócratas, protagonistas ocultos de los tumultos, para el testigo gerundense más enterado -e interesadofueron "alguna oculta mano política y hábil que hacía mover toda aquella máquina; y esta mano, ninguna podia ser más proporcionada que mano jesuítica, fecundísima en producir semejantes abortos y liberalísima cuando conviene para sostener los más excesivos gastos. Pues ¿qué otra mano hubiera podido pagar con tanta presteza los que se hicieron en aquellos dias?" 47

Para los émulos de los jesuitas, muy contestes, hubo un detalle muy significativo que contribuyó a trocar sus sospechas en certidumbre: la alegría que los rostros jesuíticos reflejaron en aquellos días amargos" ${ }^{48}$ Tal "sobrescrito de unos semblantes muy alegres

46. Martín Rich, canónigo de Gerona, AC 42-6 (2), fol. $16 \mathrm{v}$.

47. Canónigo Berga, AC 42-6 (2), fol. 30r.

48. El cit. canónigo, al atisbo de cualquier signo incluso antes de saber que se le iba a citar, prueba su convicción: "Lo quinto, porque, habiéndome puesto en observación el citado día dos de abril cómo se difundía y recibía la noticia del Motín por esta ciudad, advertí, y advirtieron 
en los Padres" ${ }^{99}$, bien recalcado por el canónigo Berga que se encargó de advertirlo a posibles despistados ${ }^{50}$, no sólo contrastó con los que vieron en los tumultos algo terrible, sino que dividió -al parecer con bastante acritud- los pareceres encontrados de unos y otros:

"Y asimismo que se vio la ciudad muy dividida en discurrir y opinar sobre el asunto, sintiendo todos estos uniformes y como de común acuerdo a favor del motín, teniéndole, al contrario, los indiferentes por cosa la más horrenda y execrable" 51.

En el fondo - $-y$ hay que verlo en todas las evacuaciones- todo obedecía al distinto concepto que se tenía de los motines. Según los testigos, para los presuntos promotores se trataba del hecho heroico de un pueblo capaz de poner a prueba su valor precisamente en este gesto de oposición al despotismo del gobierno, en concreto, de algunos ministros, como la mejor muestra de fidelidad hacia la monarquía y de "volver por su honor de españoles" 52.

Bien mirado, la sarta de acusaciones hasta el momento es la corriente en otros procesos de la "Pesquisa" fuera del ámbito catalán, como es común el ambiente e idéntico el fin al que se ordenarian después orgánicamente en el decisivo Dictamen Fiscal. Junto a ello, la investigación se orienta a arrancar signos anteriores al motin y que pudieran comprobar las complicidades buscadas. La serie de pronósticos generales, la complicación de previsiones de Torres Villarroel, dieron buen juego a Campomanes. En Gerona y

otros muchos conmigo, que los jesuitas y todos los de su bando lo iban publicanöo y comunicando a los demás con la mayor alegría y como si fuese la noticia más importante que podian tener; y de esta extraordinaria alegría no pude dejar de inferir y confirmarme más en la sospecha de que había nacido de los jesuitas el proyecto del Motín. Pues en mí mismo refiexionaba a qué vendría tanta alegría de un execrable atentado, que debía más presto causar sentimiento y disgusto (como advertí que lo tenían muchos buenos y timoratos), si los jesuitas no hubiesen sido autores y no hubieran tenido en ello tanta parte e interés". AC 42-6 (2), fol. 30v. Cfr. ibid, fol. $32 \mathrm{v}$ la alegría similar que antes sintieron los mismos reos con motivo del atentado contra el rey portugués.

49. Jacinto Gafarot, AC 42-6 (3), fol. $26 \mathrm{r}$.

50. "Item dijo que el día que llegó a esta ciudad la noticia del Motín de Madrid le hizo observar el ya citado Dn. Francisco Berga la alegría y júbilo con que los jesuitas y sus apasionados comunicaban todas aquellas noticias, como si hubiese sido la cosa más gloriosa e importante para la Compañía”. Mariano Sadurní, AC 42-6 (2), fol. 14r.

51. Narciso Farró, Beneficiado de Gerona, AC 42-6 (2), fol. 18r-v.

52. Juan Abbach, Barcelona, AC 43-3, fol. 22r; Narciso Farró, Gerona, 42-6 (2), fol. 18r; Isidoro Riera, Barcelona, AC 43-3, fol. $78 \mathrm{v}$. 
Barcelona también se hallaron pruebas "fehacientes" de haber intervenido los jesuitas en la preparación del complot; al menos de estar enterados con anterioridad a la explosión.

Las noticias - posteriores a los hechos, como es natural- decían que en Roma se tenía idea de lo que habría de acontecer en Madrid. El Domingo de Ramos, fecha del levantamiento popular, un jesuita se jactaba en la Ciudad Eterna, con cierto alborozo, "que sería bueno hallarse en Madrid para ver la bulla de un gran motín" "3. Por si fuera poco el conocido impresor Piferrer divulgó la noticia de la conversación habida con un librero italiano, escapado de la Corte momentos antes del tumulto, "porque tenía algunos antecedentes de que había de suceder el tumulto aquel mismo día, y que cree el declarante que tendría dicho librero algún aviso de los jesuitas, por ser muy apasionado y afecto a ellos" ${ }^{54}$. La insinuación -como siempre - se agiganta, una vez que pasa por la caja de resonancia de los dominicos y de Berga, y se da como cierto que sólo pudieron ser los jesuitas los que avisaron, hasta convertirse en otro de los apoyos de la petición fiscal definitiva ${ }^{55}$.

53. Francisco Cors, OFM, Gerona, AC 42-6 (2), fol. 23r; Id. canónigo Juan Andreu, ibid., fol., 27r. Este testigo cita como fuente una carta recibida por Berga - siempre el mismo- en que lo único que se dice es que en Roma los jesuitas murmuran del gobierno; el canónigo, no obstante, está convencido de esta "presciencia", puesto que a los ocho días del estallido ya lo comunicaban a los Regidores de la ciudad de Gerona, noticia "que era imposible haberlo sabido por la vía de la Corte, a no haberla tenido o anticipada o por correo expreso". AC 42-6 (2), fol. 30r, 31r. Coinciđen, además, la mayoría de los testigos cuando declaran sobre la convicción romana: Francisco Befarás, AC 42-6 (3), fol. 6v-7r; Lucas Gallet, ibid., fol. 24r. El testigo principal de Barcelona, Juan Abbach, depone "haber oído decir al P. Maestro Fr. Agustín Voltas, Dominico, que en Roma se anunciaba ya el tumulto de Madrid antes de suceder", AC 43-3, fol $22 \mathrm{v}$. Esta carta del dominico - no del canónigo- es el origen auténtico de la acusación. Obsérvese en la deposición de Voltas la transfiguración sufrida después, pues el único argumento en que se basa es en el silencio que guardaron los jesuitas romanos cuando se enteraron de la elevación de Aranda, en contraste con las murmuraciones anteriores contra el gobierno. La acusación de la noticia previa del motín en Roma se repite en casi todos los testigos de Barcelona. AC 43-3, fol. $28 \mathrm{r}$.

54. Tomás Piferrer, AC 43-3, fol. $77 \mathrm{r}$.

55. El librero se llamaba Carlos Lossi, según el testimonio de su colega catalán, que le conocia personalmente (los restantes hablan de oídas). A este "avance" del motín se refieren numerosos testigos como una de las pruebas más fehacientes de la participación jesuita en él. Berga, 42-6 (2), fol. 38r; Pedro Pla, OP, AC 43-3, fol. 31r; Vicente Cortés, OP, ibid., fol. $75 \mathrm{r}$; Domingo Fuster, OP, ibid., fol. $82 \mathrm{v}$. 


\subsection{La oposición jesuitica al gobierno de "jansenistas"}

Las acusaciones anteriores fueron decisivas y era lo que esperaba Campomanes. No hay duda de que ninguna de ellas evidencia la participación directa y corporativa de los jesuitas en los motines; pero el Fiscal sabrá envolverlas y adobarlas debidamente para asustar al real desánimo de Carlos III, aún no recuperado del espanto de los motines madrileños -los de provincias no le afectaron tanto-. Este ambiente se consigue al presentar el cuerpo de la Compañía como elemento irreconciliablemente hostil al gobierno y al monarca. Es lo que comunicaría después Roda, desvinculado del solemne juramento del sigilo, a Tanucci, en una minuta aleccionadora que resume las razones que movieron al rey español a firmar la sentencia, precisamente en fuerza de las acusaciones recogidas en la "Pesquisa":

"De todo resultó que los jesuitas eran el principal o único fomento que atizaba el fuego por todas partes, indisponía los ánimos de toda clase de gentes, los separaba del amor y subordinación al gobierno, imprimian y esparcían papeles y escritos sediciosos y contrarios a la autoridad real y a la soberanía y sus legítimos derechos. Predicaban contra Portugal y Francia en sus sermones al público $\mathrm{y}$ en los locutorios de las monjas, introduciéndose a confesarlas y dirigirlas sin autoridad y contra la voluntad de los superiores de los conventos. Infundian hasta en los claustros de las religiosas, en sus pláticas y conversaciones, máximas perjudiciales $\mathrm{y}$ sospechas indignas contra la religión del rey y sus ministros. Amenazaban desgracias y tragedias en tono de profecías antes y después del tumulto. Se quejaban de todas las provisiones que se hacían, por no recaer los empleos y dignidades en sus parciales y secuaces de su escuela. Murmuraban de todas las providencias del gobierno, porque no tenían parte en ellas y por ser contrarias a sus ideas y ventajas (...). Su odio a la Casa de Borbón y su aversión al Pacto de Familia, su parcialidad por los ingleses $y$ sus deseos de que éstos oprimiesen a la Francia, la mayor satisfacción y confianza que ponen en los príncipes protestantes, prefiriéndolos a los católicos, y otros objetos abominables y contrarios al espiritu de religión, de honor y de humanidad, se han comprobado por muchos medios irrefragables que nos han suministrado sus propios hechos y escritos" 56 .

$Y$ el alegato, cuya sustancia hemos encontrado en este largo párrafo, sigue con palabras que parecen extraídas del Dictamen de Campomanes y de la "Pesquisa". El secretario de Gracia y Justicia,

56. Minuta de carta de Roda a Tanucci, 24 junio 1767 (Original autógrafo de M. DanviLA, que reproduce en su o. c., III, p. 637). 
como es natural, estaba bien informado, y los testigos catalanes desgranaron las mismas acusaciones, aunque con pasión que a veces imposibilita distinguir lo que corresponde a la opinión y lo que obedece a una transfiguración subjetiva. Del contexto se desprenden, entre la marea de inculpaciones, dos capítulos fundamentales: la oposición jesuítica al gobierno (a los gobernantes y sus iniciativas), por una parte, y al rey Carlos III -es decir, a la monarquia entera de los Borbones- por otra. Más adelante nos fijaremos en sus posturas "antiborbónicas"; por el momento nos ceñiremos a su actitud antigubernamental, sí bien no siempre resulta fácil desligar ambos elementos.

Desde este punto de vista, los motines madrileños se presentan como la expresión violenta de una oposición a los gobernantes de 1766 (al menos a los gobernantes más significados) y como episodio de posturas inveteradas. Se trataria de la intentona de un golpe de Estado perfecta o imperfectamente planeado por los jesuitas y el sector social y político (aristocracia, colegiales mayores) coincidentes con sus intereses, pero siempre dentro del contexto de la oposición política al gobierno. La Compañía, a estas alturas, se había tornado en la aliada envidiable - y desventurada - de tantas ofensivas como desde comienzos del siglo XVIII desencadenó el "Partido Español" contra el nuevo sistema o contra los personajes nuevos en formidables campañas de "opinión" ${ }^{57}$.

Por los contornos de 1766 se conjugan todos los factores constantes y coyunturales favorables a la explosión: crisis de subsistencia -aunque no se haya matizado aún su alcance real, y menos en Madrid, más abrigado a tales sacudidas por la organización de su abastecimiento-, proyectos de reformas desamortizadoras con el clero y señores como víctimas, equipo de gobierno con dos extranjeros en los puestos decisivos, y "golillas" (Carrasco, Campomanes,

57. En obras anteriores hemos analizado esta historia del "Partido castizo" de la oposición. Tuvo fuerte influjo al final de Patiño, y su expresión más genuina es el periódico satírico que en 1735 lanzaba "El Duende": (Cfr. nuestro Prensa clandestina española en el siglo XVIII, Valladolid, 1968. Su dinámica y principales momentos, durante toda la primera mitad de este siglo, cfr. en Opinión pública $y$ oposición al poder en la España del XVIII (1713-1759), Valladolid, 1971. Su prehistoria y proyección posterior hasta 1808, en Sátiras políticas de la España Moderna, Madrid, 1973. Un estudio muy claro, aunque el autor lo plantee como hipótesis de trabajo - personalmente opinamos que hipótesis muy consistente- cfr. en C. E. Corona, "Sobre el tránsito del absolutismo al liberalismo, ya cit. 
Roda) actuantes como auténticos cerebros grises a la sombra o al descubierto. El intento de reformar el traje "nacional", la actuación de las tropas walonas desde el año anterior, su impopularidad, todo se conjuró para que, so pretextos claramente xenófobos, el motín organizado se dirigiera contra Esquilache ${ }^{58}$. Cuando el movimiento "popular" madrileño, con tipología peculiar de "motín de Corte", contaminó las provincias, y, después de reprimido en su fase aguda, se quiso dar con los responsables de todo, las pesquisas se orientaron hacia los autores de sátiras, invectivas, papeles denigratorios, conversaciones, sermones con alusiones contra el gobierno.

Dado el giro que tomaron las investigaciones, la división que conscientemente se consiguió entre el clero, la filtración de noticias, $y$, sobre todo, la sospecha de que en España se caminaba hacia medidas de extrañamiento similares a las anteriores de Portugal y Francia, los jesuitas reaccionaron de la manera más normal, y poco costó a los pesquisidores centrar la atención en expresiones antigubernamentales.

Por su parte, hubo imprudencias, y es indudable que antes, en el tiempo y después de los motines, se pronunciaron contra el ritmo de un gobierno despótico, reformista y "jansenista" (es decir, antijesuita y regalista), según ellos. Danvila, Rodriguez Casado y últimamente Corona, han puesto a disposición del historiador documentos sobrados para medir la real alianza ocasional de los jesuitas con el antiguo "Partido" de la oposición al absolutismo borbónico ${ }^{59}$. Son testimonios casi siempre privados, procedentes de correspondencia particular y confidencial interceptada por la red de espías y delatores al servicio del fiscal. Las expresiones y actitudes públicas están recogidas, en buena parte, en la "Pesquisa", en la que hay que desbrozar lo tendencioso de lo auténtico, dada la pasión que bulle a borbotones violentos en las deposiciones inevitables y universalmente hostiles.

Hay que partir del presupuesto de que, salvo alguna voz disonante, es unísono - sospechosamente unísono- el coro desbordado que coincide en la cadencia reiterada y regular: "Dijo que sabe que los jesuitas han hablado y hablan contra el gobierno"; "que

58. Cfr. nota 72 y la versión original que da un testigo de los hechos.

59. Claramente expuesto en C. E. Conona, a. cit., y en "Sobre el conde de Aranda y sobre la expulsión de los jesuitas". 
también sabe han escrito los jesuitas varios papeles injuriosos contra el rey y sus ministros, remitiéndolos por correo a varios sujetos"; que los apasionados de los jesuitas "en dichas conversaciones han hablado con tanta libertad, que no han perdonado la sagrada persona del rey" ${ }^{60}$. Aunque no se distinga - no hay interés en hacerlo- lo oído de los jesuitas y lo escuchado a los incontables afectos, y a pesar de que la mayor parte no hable por experiencia personal sino que transmita "la voz común", lo que "es público y notorio" en la respectiva ciudad, la coincidencia de esta fuente frágil con otros documentos procedentes de los propios jesuitas es el mejor comprobante de la alianza de la Orden - no decimos que consciente- con el frente de oposición más general y no bien conocido aún.

Como raíz próxima de su actitud puede verse el rumbo último de los sucesos que los van marginando de determinados resortes del poder "como no se ven tan pujantes, ni tienen el valimiento como antes, se observan y manifiestan agriados y resentidos del gobierno de S. M." ${ }^{61}$. Pero la lucha por el retorno al poder no puede cifrarse sólo en una reacción de resentimiento, muy comprensible por otra parte en un clero tan politizado como el de 1766; existen otros motivos transcendentales y también más episódicos, que confluyen en el enfrentamiento con el gobierno.

El más inveterado y universal es el de la concepción y práctica del sistema gubernamental. Sería anacrónico identificar las quejas de los "apasionados" con un liberalismo precoz; pero tampoco sería correcto ignorar la apoyatura antidespótica que palpita en la dignificación del motín, "porque el rey no podía atropellar a sus vasallos y que había que respetar las leyes del reino; y que como S.M. no había dado oídos a las representaciones que se le habían hecho repetidas veces, viéndose el pueblo tiranizado por Squilace, quiso sacudir el

60. Juan Abbach. AC 43-3, fol. 20r-22r. En tonos parecidos: Pedro Pla, ibid., fol. 30v; Angel Pla. ibid., fol. 68v; Angel Molas, ibid., fol. 70r; Jaime Sentyes, ibid., fol. 73v; Vicente Cortés, ibid, fol. 74v; Tomás Piferrer, ibid., fol. 76v; P. Riera, ibid., fol. 78v; Domingo Fuster, ibid., fol 80r; Juan Borrás, ibid., fol. 103v; Joseph Vall, ibid., fol 111v; y en Gerona AC 42-6 (2) Felipe Bojons, fol. 5v; Mariano Sadurní, ibid., fol. 14r; Francisco Cors, ibid., fol. 22v, si bien en Gerona se asimila el hablar mal de las medidas antijesuiticas de Francia y Portugal con las murmuraciones del gobierno español. Otros testigos asimilan la figura del P. Isla a algunas de las invectivas lanzadas contra los gobernantes: Angel Pla, AC 43-3, fol. $68 \mathrm{v}$; Riera, ibid., fol. $80 \mathrm{v}$.

61. Francisco Befarás, notario mayor del obispado de Gerona, AC 426 (2), fol. $7 \mathrm{r}$. 
yugo que suponía insoportable" ${ }^{62}$. A este motivo general hay que achacar la recriminación lanzada al parecer por algunos jesuitas en Gerona contra la reciente institución de los Diputados y Personeros, "dicendo que es deshonor de los ayuntamientos, poca confianza en los Regidores" (sin olvidar que en Gerona buena parte de los Regidores eran "apasinados" fervientes de los jesuitas) ${ }^{63}$.

La "Pesquisa", no obstante, no se muestra en exceso elocuente sobre el particular de la oposición al regalismo. Sería Campomanes, en su prolijo Dictamen, el que extrajese las últimas conclusiones; en la investigación previa lo que se desgrana es un cúmulo de quejas más inmediatas, forzadas por la observación de los signos ambientales por parte de los jesuitas y por el temor a que en España se abocase a las medidas radicales portuguesas y francesas. Tal es el contexto preventivo que respiran las conversaciones "delictivas", los sermones a'armados que predica el $P$. Casanovas en la festividad de S. Ignacio en Cervera ("¡Oh, madre Compañía! ¿Cuándo dexarán de perseguirte los tiranos?"), el P. Blas en Lérida, en Gerona ${ }^{64}$, donde se manifiestan dolidos de los gobiernos de Francia y Portugal, y, como consecuencia, "del gobierno de España, con expresiones indirectas"; de que "España en orden a los jesuitas se había vuelto Francia"; "que se introducía el jansenismo en el ministerio de España"; "que en España se introducía la herejía"; que "el Evangelio estaba en las botas para salir de España" ${ }^{65}$.

Las críticas contra los gobernantes concretos personalizan los

62. Juan Abbach, AC 43-3, fol. 22r.

63. Francisco Cors, AC 42-6 (2), fol. 24:r.- Sobre Diputados y Personeros, y su importancia a raíz de los motines, cfr. M. Defourneaux, Pablo de Olavide ou L'Afrancesado, p. 89ss.- Para evitar malos entendidos advirtamos que estas murmuraciones antiabsolutistas de los jesuitas acaban diciendo que este robo de la iniciativa municipal tendria como contrapartida "dar de mano a gente baja para que se haga insolente" (ibid.).

64. Juan Abbach, AC 43-3, fol. 23v; Francisco Cors. AC 42-6 (2), fol. 22r ; Pedro Trutxet, AC 42-6 (3), fol. 15v. del sermón del P. Blas envía Roda un extracto a Aranda, 25 sept. 1767, (AGS, Gracia y Justicia, Leg. 1.009).

65. Pedro Pla, AC 42-6 (2), fol. 31v; Felipe Bojons, ibid., fol 5r; Francisco Berga, ibid., fol 32r; Jacinto Gafarot, AC 42-6 (3), fol. 28v; Angel Molas, AC 43-3, fol. 70r; Vicente Cortés, ibid., fol. 74v; Tomás Piferrer, ibid., fol 76v; Isidoro Riera, fol. 78v: "Sabe que los jesuitas han hablado contra el gobierno, y que esto lo sabe asi por ser público y notorio en la ciudad, como también porque, hallándose el declarante en la de Gerona, oyó decir también allí que los jesuitas se manifestaban muy sentidos y quejosos del ministerio". Domingo Fuster, ibid., fol. 80r; Pablo Bordius, ibid., fol. 98r; José Vasiana, ibid., fol. 94r; Juan Borrás, ibid., fol. 103v; Bernardo Vilaseca, ibid., fol. 108v; José Vall, ibid., fol 111v. 
blancos predilectos a tono con los motivos e intereses que fuerzan y explican las raíces de la oposición jesuítica.

Lo más extraño - mejor, dicho, lo más natural si tenemos en cuenta lo apuntado acerca de los directores verdaderos de la operación-es que, contra lo que cabría esperar, el Conde de Aranda, presidente del Consejo de Castilla y responsable nominal de la "Pesquisa", no sale malparado de tantas murmuraciones como espias movilizados al efecto recogieron de boca de jesuitas y "terciarios". Se confirman de esta forma tesis como las de Olaechea y Corona, basadas en otra documentación ${ }^{66}$, y es revelador que los prolijos Berga y Gafarot, que acumulan y sistematizan todos los indicios posibles eimposibles, no den señales de la animosidad esperada contra el flamante presidente. Este mismo silencio hacia Aranda se siente en el resto de los declarantes, muy explícitos a la hora de dar los nombres de las víctimas de la oposición. Cuando el silencio se quiebra es para abonar la simpatía existente entre los jesuitas y el Conde, aunque se deduzca de forma indirecta. Tal sucede con los rumores esparcidos por Barcelona acerca de la libertad demasiada con que en Roma hablaban contra el gobierno ciertas lenguas incluso antes de los motines, "pero que enmudecieron luego que se supo en Roma que se había nombrado presidente del Consejo al Excmo. Sr. Conde de Aranda" ${ }^{67}$. No hay misterio alguno en este enmudecer: en la ciudad lejana de Gerona un testigo "había oído que se tenía por cierto que cuando S. M. creó presidente del Consejo al Excmo. Sr. Conde de Aranda mostraron los Padres singular alegría, y decían que mudarían de semblante las cosas de la Compañía, porque era muy suyo $S$. Exca., pues eran sus confesores, directores y consultores jesuitas" ${ }^{68}$.

66. Si era posible sospechar que las relaciones Aranda-Jesuitas no fueron tan hostiles como algunos historiadores las presentaban, la sospecha se tornó en seguridad después del trabajo de R. Olaechea, "En torno al ex-jesuita Gregorio Iriarte, hermano del conde de Aranda", en Archivum Historicum Societatis Iesu 33 (1964) 157-234. Cfr. también, ID., El Conde de Aranda y el "Partido aragonés", p. 75 ss y C. E. CoronA, "Sobre el Conde de Aranda", p. 89-96.

67. Agustín Voltas. AC 43-3, fol. 28v, que confirma lo declarado por el Capitán Abbach, ibid., fol. 22v.

68. Francisco Cors. AC 42-6 (2), fol. 23v-24r. Claro que el testigo no disimula el temor que tienen los jesuitas de unos meses a esa parte; pero también se đáa la explicación de que todo obedece al cerco tendido sobre Aranda: "Y que el abogado Dn. Narciso Riera le aseguró que su tío, el P. Narciso Riera, jesuita, hablando de dicho $5 r$. Excmo. en casa de su padre, en su presencia y de otro tío canónigo de la catedral, hermano del citado jesuita, dijo: "El Sr. Aranda hará como los otros, también caerá, pues no le faltarán émulos". 
Por el contrario, las críticas se ensañaron contra el cuarteto integrado por Esquilache, Campomanes, Roda y el Padre confesor del rey, aunque con desigual dureza ${ }^{69}$." Que el confesor era un adulador, que el Sr. Marqués de Esquilache era un cabrón y que el Sr. Roda era un jansenista" ${ }^{70}$, no fueron los apelativos más duros que se lanzaron por aquellas circunstancias.

A Esquilache se le atacó virulentamente antes del motín y hasta su expulsión de España; las sátiras, pasquines, relaciones coetáneas confirman algo bien sabido incluso por la documentación oficiál. Lo novedoso resulta de que -naturalmente -en la "Pesquisa" se hace responsables exclusivos de las invectivas contra el ministro extranjero a jesuitas y "apasionados" ${ }^{71}$. De todas formas, una vez caído desaparece de la escena española, aunque no del recuerdo de la literatura clandestina de agitación ${ }^{72}$.

Alejado Esquilache, las críticas se endurecen contra Eleta (o el P. Osma, confesor real), Campomanes y Roda: públicamente decían los jesuitas "que ahora gobernaban a España un fraile y dos jansenistas", en alusión demasiado fácil de identificar ${ }^{73}$.

69. Felipe Bojons, 42-6 (2), fol. 5v; Jerónimo Puig, ibid., fol. 10r; Francisco Cors, ibid., fol. 22v; Berga, ibid., fol. $31 \mathrm{v}, 32 \mathrm{r}-\mathrm{v}$, donde también dice que se habla con cierta libertad de Grimaldi y duque de Frias.

.70. Mariano Sadurní, AC 42-6 (2), fol. 14r-v: "Que los ministros habían sacado la putas de Madrid pero no las suyas, y tiene por cierto que todas estas voces salian de la Compañia, porque sus secuaces eran los que más se esforzaban en propagarlas".

71. "Item dijo que para cohonestar los jesuitas y sus passionados el motín decian que la Junta de Abastos en Madrid era insufrible, y que de lla nacía la suma carestía de los víveres; y que el ministro era un ladrón y había empobrecido el erario real, interesaba ocultamente en ello como en otras muchas cosas; y que después se esparcieron que esta obra (la del motín) no podía dejar de envolver el apoyo de un personaje o personajes, pues semejante empresa excedía el valor de la plebe". AC 42-6 (2), 18v.

72. El testigo Berga hace verdaderos equilibrios para conciliar la opinión común de las buenas relaciones de los jesuitas con las dos víctimas del motín (Esquilache y el Obispo Rojas, Presidente de Castilla) y cargar la responsabilidad de los tumultos exclusivamente sobre la Compañia: "Me hizo entrar más en la sospecha de que había nacido de los jesuitas el proyecto del motín, por haberse únicamente dirigido las demostraciones de los amotinados contra el Excmo. Sr. Marqués de Esquilache y contra el Itmo. Sr. Obispo Gobernador del Consejo, siendo estos dos señores, según pública voz y fama, afectos a los jesuitas; pues se me previno luego, que la política y refinada disimulación de estos PP., para mejor ocultar la mano, se había dirigido más presto a sacrificar a los dos sus apasionados que a los demás señores del ministerio de conocido sus odiados, para que jamás pudiese recaer la sospecha contra los mismos jesuitas de ser los verdaderos autores del motín". 42-6 (2), fol. 30r-v.

73. Isidoro Riera, AC 43-3, fol. $79 \mathrm{r}$. 
Contra Campomanes tenian los jesuitas motivos de queja. El año anterior habia publicado su Tratado de la Regalia de amortización ${ }^{74}$, proyecto frácasado por prematuro y porque no contó con la fuerza del clero afectado y de las clases privilegiadas, pero que indicaba con claridad sobrada la mentalidad fuertemente regalista del activo Fiscal de Castilla. Los jesuitas, que desde el exilio lanzarían auténticas campañas de opinión contra su figura ${ }^{75}$, en la "Pesquisa" no dan tanta importancia al Tratado (quizá porque en el programa "desamortizador". no fuesen ellos los más perjudicados) ${ }^{76}$ cuanto a su intervención ante el Consejo de Castilla, intervención "que corrió por España" y factor decisivo que vedó la admisión de los expulsos franceses; ello bastó para que se percatasen de las predisposiciones de don Pedro Rodríguez y constituyó el motivo fundamental - si no hubieran visto más - por el que "le calumniaron y graduaron de jansenista, con todo el desprecio que tal calificativo denigrante entrañaba para los ultramontanos ${ }^{77}$.

En ritmo ascendente, y como el mayor de los jansenistas y regalistas -esta última denominación no le molestaba demasiado a él- la oposición de los jesuitas al gobierno adverso se centró con especial violencia sobre Roda ${ }^{78}$. Del secretario de Gracia y Justicia decía el otro aragonés Azara que "por el un cristal de sus anteojos no veía más que jesuitas y por el otro colegiales mayores" ", male-

74. Cfr. la reciente eđición, introducida por Francisco Tomás y Valiente, Madrid, 1975. El propio Archivo de Campomanes conserva buena documentación no explorada hasta el momento acerca del proceso de este documento y de su suerte posterior.

75. Una buena muestra -entre las muchas que se podrian citar- de estas campañas posteriores a la expulsión contra Campomanes puede verse en la documentación citada por R. Olaechea, "El concepto de 'exequatur' en Campomanes", en Miscelanea Comillas, 45 (1966), Separata: Y, por el contrario, el fantasma jesuítico perseguido por el Fiscal años después, cfr A. Domínguez Ortrz, "Campomanes, los jesuitas y dos hermandades madrileñas", en Anales del Instituto de Estudios Madrileños 3 (1968) 219-224.

76. O quizá también por lo relativamente moderado del proyecto, como ha visto Tomás y Valiente, en el "Estudio preliminar" cit.

77: Así se lo oyeron los declarantes al P. Puig, provincial de los Trinitarios Calzados -una de las Ordenes no enfrentadas con los jesuitas-, "muy apasionadísimo de jesuitas", y así se corrió por Gerona y Barcelona. Gafarot, 42-6 (3), fol. 27v-28r; Jerónimo Puig, OP, AC 42-6 (2), fol. 10r.

78. "Dicho P. Maestro (Puig) es uno de los más apasionados de los Jesuitas. $\mathrm{Y}$ asimismo dice haber oído a muchos padres de su convento que tratan con los apasionados a los jesuitas, que se hablaba muy mal del Sr. Roda y que era ya entre éstos tenido por jansenista”. Jerónimo Puig, AC 42-6 (2), fol. 10r; Francisco Berga, ibid., fol. 38v.

79. En OlaECHEA, Las relaciones, I, 239. 
dicencia cuya exactitud se encargan de probar los hechos y los documentos. Los jesuitas y apasionados, en contrapartida, no perdonaron ninguno de los flancos a una persona tan resentida como eficaz y escasamente conocida ${ }^{80}$. Los términos de la Gaceta al promulgar su elevación en 1765 a la Secretaría parece que dieron ya motivo de burla ${ }^{81}$. Pero la historia del resentimiento jesuita era más larga y profunda, y hay que retrotraerla a la caída del último confesor real de la Compañia, P. Rávago.

En otra circunstancia hemos analizado el significado de la desaparición de uno de los miembros más decisivos del equipo de Ensenada. Las malas lenguas de aquel 1755 se encargaron de pronosticar la relación entre el alejamiento del confesor y la suerte final de la Compañia.

$$
\begin{aligned}
& \text { "Ya, mudado el gobierno, } \\
& \text { no será presunción vana, } \\
& \text { que les quiten la sotana } \\
& \text { a la entrada del invierno". }
\end{aligned}
$$

Si las sátiras de entonces fallaron en la profecia del momento, pusieron en claro algo que debía saber todo el mundo: que el confesonario regio tenía que ver menos con la dirección de la real conciencia que con la colación de beneficios eclesiásticos —al margen de otras competencias-, prácticamente monopolizados por quien en la circunstancia concreta de España jugaba el papel -y Rávago lo jugó bien- de "papa, rey y confesor en un sujeto";

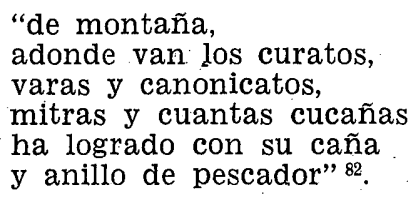

Diez años después todo este poder fabuloso descansaba sobre Roda que no disimuló su voluntad de cambiar frontalmente esta política. Su práctica deliberada se centrará en desviar las prebendas hacia los "golillas", y con ello asestar un golpe decisivo a la potencia de los jesuitas y, simultáneamente, a los colegiales mayores, candidatos predilectos y casi únicos en las anteriores expectativas.

80. Cfr. R. Olaechea, o. c., p. 237 ss.

81. Francisco Cors, AC 42-6 (2), fol. 23v.

82. T. EgrDo, Opinión pública y oposición al poder, p. 219-225. 
Con ello erosionaría el poder de otro frente social formidable, pues - aunque la conclusión no resulte exacta en todos sus detalleses muy difícil desvincular el bloque de los "colegiales" del sector social aristocrático, y el de los "golillas" de una cierta burguesía (o hidalguía, aunque parezca paradójico) de letrados, en pugna antañona y enconada.

Y éste será el flanco por el que los jesuitas, decididos a dar la batalla antirregalista, aunque los resultados tomaran caminos imprevistos, atacaron a Roda antes y a raíz de los motines. La acusación se reitera en términos casi idénticos por testigos distintos:

\begin{abstract}
"Y habiéndose ofrecido hablar en la conversación de la expectación en que se estaba de las primeras gracias eclesiásticas que se hiciesen por conducta o influencia de dicho Secretario, tomó la voz dicho P. Durán y empezó a declamar y hablar mal de la despotiquez o mala conducta de pender las provisiones aquellas de un sujeto secular y Secretario, que las haria precisamente por respeto a sus hechuras y parciales, sin entrar por la puerta del mérito. Que para este atajo, ¿no era mejor poner una Dataria de algunos obispos o prelados, por cuales se hiciesen los nombramientos? Pero "que allá iban las leyes donde querian los reyes", con modo y aire al paso que mofoso, pero nada sufroso, y antes resentido. Y luego por transición pasó a referir cuán pocas Capillas habia mitradas en España, y añadió también con aire insultante y burlesco: "ahora verán los señores regulares si era el P. Rávago la causa de no mitrar ellos, como por envidia se lo atribuian; pero que otro vendría que le alabaria", como que presuponia que las cosas irian de peor forma" ${ }^{83}$.
\end{abstract}

En cuanto al confesor, P. Eleta, es hondo menosprecio vulgar el que se derrama en las invectivas recogidas de boca de los émulos jesuitas. Hay quien cree que el motín fue desencadenado por ellos para recobrar el bastión del confesonario real ${ }^{84}$; incluso se llegó a esparcir el rumor deliberado y desconcertante durante los mismos motines de que el P. Osma (el confesor) ya había sido sustituido, asimilando su suerte a la de Esquilache ${ }^{85}$. Pero es el insulto lo que fundamentalmente se esgrime contra alguien que secundaba

83. Jacinto Gafarot, AC 42-6 (3), fol. 29r-v. En tonos parecidos: J. Cors, AC 42-6 (2), fol. 23v-24r ; Berga, ibid., 33r., 36r. Llampillas se queja de "en España sólo se pensaba en reformar la Iglesia", Joseph Vall, AC 43-3, fol. $112 \mathrm{r}$.

84. Jerónimo Puig, AC 42-6 (2), fol. 10r.

85. "Y al Itmo. P. Fr. Joaquín de Osma (que suponian ya exonerado de su empleo) le daban por sucesor unas veces al Excmo. y Rmo. P. Molina, General de la Orden de San Francisco, otras veces al Ilmo. Sr. obispo de Osma". Francisco Berga, AC 42-6 (2), fol. 32v-33r. 
la política regalista del gobierno (olvidando lo acaecido con Rávago): se divulgaba que "el Ilmo. Sr. confesor era un tonto y adulador, que era alpargatilla y que hacía hacer a S. M. cuanto queria" ${ }^{86}$. El activo hermano Ignacio Baldo no cejaba de decir por Gerona "del IImo. P. confesor de S. M., Fr. Joaquín de Osma, que es un ignorante, una pobre alpargatilla, sin letras, mofando de él porque dice que iba a caballo a la caza cuando salia a ella S. M." ${ }^{87}$.

5.3. La monarquía borbónica cuestionada, la tradición regicida y la doctrina de los polvos mortiferos.

El proceso contra los jesuitas, en esta fase previa de las investigaciones, deja entrever ya la voluntad superior de conectar los motines españoles de 1766 con actitudes y convicciones antimonárquicas de la Compañía. Habia que evidenciar al rey que los jesuitas eran enemigos de la monarquía absolutista en general y de la suya en particular; y había que presentar a un monarca acobardado, que, nì a retornar a Madrid se atrevía, a pesar de los cumplimientos de toda la villa y de las urgencias de Aranda, la interdependencia de episodios violentos recientes con el riesgo constante que suponía la misma existencia del cuerpo que los protagonizara. Una maniobra, no demasiado hábil pero contundente, por parte de Campomanes supo coordinar todos los elementos ambientales de aquellos meses, dar vigor a otros pretéritos, ofrecer un cuadro entre exacto y tendencioso de la imposibilidad de conciliar la línea de Carlos III con el ultramontanismo evidente y el antirregalismo de los jesuitas, aislar a los numerosos "terciarios del cuarto voto", para recabar el asentimiento del real ánimo a un proyecto cuyo desenlace se aceleró sorprendentemente.

La "Pesquisa secreta" fue el instrumento envidiable que dio materia al Fiscal y argumentos a las insistencias de Tanucci, al empeño de Roda. La parte que hemos podido estudiar así lo comprueba. El recuerdo de doctrinas regicidas jugó buen papel contra la escuela probabilista, y la investigación sobre los libros y sermones del P. Calatayud en Vizcaya se dirigió a sorprender la penetración de tales ideas delictivas ${ }^{88}$.

86. Ibid., fol 38v.

87. Gafarot, AC 42-6 (3), fol. 27v; Juan Bono, ibid., fol. 17r.

88. AC 42-4: 
Mas, en un proceso de esta índole, interesaban tos hechos en mayor medida que las ideas. ' $Y$ ahi estaban; relativamente recientes, los casos de Portugal y Francia que ocupan amplios espacios en las declaraciones hostiles. Se acusa a los jesuitas de protagonismo exclusivo en la oposición sangrienta a los reyés vecinos y se les recrimina intentos regicidas, más claros en el reino de Portugal. Por eso -es cansina la cadencia de los testigos- los jesuitas son :los peores enemigos acérrimos del rey, y Carlos III tiene motivos para temerlos,.. "por ser sobradamente sabịdo [...] cuán resentidos, enojados y preñados andaban y vivían los PP. jesuitas en este reino desde la caída del P. Rávago del confesonario del Sr. Rey D. Fernando Sexto (que Dios haya)", y "por ser cosa notoria que han propendido $\mathrm{y}$ : procurado los jesuitas semejantes alborotos y haber atentado a las vidas de los monarcas en los casos que debían pensar ser el medio más beneficioso, convenciéndolo de toda satisfacción los modernos atentados de Francia y Portugal" ${ }^{89}$.

Fueron meses en los que Carvaiho se encontró con un frente insólito de defensores y el "mártir" Malagrida con una nube de detractores, quienes, por otra parte, no salian de su asombro ante el atrevimiento de que hubiere quien $-y$ éste quien eran sólo los jesuitas - osara murmurar del "licencioso modo de vivir o amancebamiento de S.M. Cristianísima con Madama Pompadó" o de las relaciones de la otra Majestad Fidelísima con la duquesa de Aveiro ${ }^{90}$ : $Y$ fueron meses en los que Carlos III vio cómo por todas partes se le presentaba el fantasma de un cuerpo tan peligroso para su monarquía. Porque resultaba, tal como se le informó, que los jesuitas no sólo fueron los autores formales y materiales de los motines madrileños, de los de provincias, y en especial del registrado en Loyola, sino prácticamente de cuantas turbulencias se dieron desde siglos antes en "Venezia, Inglaterra, Polonia, Francia, Portugal, Bohemia, Moravia, fomentando calumnias contra el Estado y sus ministros, hasta llamar al Turco en su socorro contra dicha república de Venezia" ${ }^{91}$. Campomanes los haría responsables de la secesión portuguesa en el siglo anterior, y en Barcelona y Gerona

89. Gafarot, AC 42-6 (3), fol 26r; Berga, AC 42-6 (2), fol: $34 \mathrm{r}$.

90. Mariano Sadurní, AC 42-6 (2), fol. 13v; Gafarot, AC 42-6 (3), fol $27 \mathrm{r}$; Antonio Aloy, ibid., fol. $14 \mathrm{r}-\mathrm{v}$, y se repite en casi todos los testigos.

91. Juan Abbach, AC 43-3, fol. 22v; Raimundo de Irabién, ibid., fol. 87r; el catálogo de revoluciones provocadas por los jesuitas se amplịa aún más en Berga, AC 42-6 (2), fol. 29r. 
de haber querido alarmar a Mina, forzándole a tomar medidas rigurosas e innecesarias - pero provocativas - cuando la población se encontraba la mar de tranquila ${ }^{92}$.

Escalonadamente se acumulan acusaciones tendentes a acentuar la peligrosidad de la colectividad inobediente "que imprime papeles injuriosos", que no perdona "la sagrada persona del Rey", de la que "hacen zumba y mofa". turísticos y, vista la persecución desencadenada contra su familia, se atreven a decir en sus sermones: "quién sabe, quién sabe si por los pecados de España querrá Dios que venga otro príncipe" 94; que le tachan de "perseguidor de la Iglesia" 95; que le endosan los epítetos de "tonto, y, sobre todo, de muy temerario, simple, ignorante y demente" ${ }^{96}$, de incapaz de hacer nada por propia iniciativa una vez que falleció su mujer, que de verdad "era la que reinaba y gobernaba" ${ }^{97}$.

Y, por si fuera poco, al pobre rey las habladurias que salian "de esta fragua" de jesuitas y apasionados le colgaron el sambenito de amancebado. Los deponentes de Gerona creyeron que la murmuración partió de la portería del colegio de la Compañía, pero no era sino el eco de algo que corrió también por Madrid. Eso sí, en la

92. Las mediäas del marqués de la Mina en Barcelona. cuyo vigor puede verse como prevención eficaz contra posibles convulsiones al estilo de Madrid o Zaragoza, se explica por los testigos: "Cree el testigo que todo esto se hizo únicamente por dichos padres con el fin de mover los ánimos de estos naturales que se hallaban en la mayor tranquilidad". Juan Abbach, AC 43-3, fol. 24r; Joaquín Troch, ibid., fol. 91r; José Vasiana, ibid., 94v; José Izquierdo, ibid., 96r; Pablo Bordius, ibid., 98v; Peđro Costansó, ibid., 101r; Juan Borrás, ibid., 104r ; José Vall, ibid., 112v. Berga, AC 42-6 (2), fol. 30v; AC 42-6 (3), Gafarot, fol. 28r.- También se interpreta como incitación jesuítica al motín, y como ensayo de lo que se haría llegado el caso, el tumuito interno y la capitulación del Colegio de Cardellas, AC $43-3$, fol. $24 \mathrm{v}$, Juan Abbach, repetido por bastantes testigos barceloneses.

93. Juan Abbach, AC 43-3, fol. 20v; Cors, AC 42-6 (2), fol. 22v; Gafarot, $\mathrm{AC} 42-6$ (3), fol. $27 \mathrm{r}$.

94. Juan Abbach, $\mathrm{AC} 43-3$, fol. $23 \mathrm{r}-\mathrm{v}$.

95. Jaime Ferrer, AC $42-6(2)$, fol. $7 \mathrm{r}$.

96. Jaime Ferrer, ibid., fol. $7 r$; Mariano Sadurni, ibid., fol. $14 r$; Juan Bono, ibid., fol. 18r; Francisco Barris, AC 42-6 (3), fol. 21v; Berga, AC 426 (2), fol. $31 \mathrm{v}$.

97. "Y que su dignísima consorte, D. María Amalia, que de Dios haya, era la que reinaba y gobernaba, y aún la que le hacía lucir y que le sugería lo que debía decir y hacer en funciones públicas y secretas, que por esto después de su muerte fue corriente entre ellos (los jesuitas) que todo el gobierno y su modo mudaría enteramente, cediendo todo, y diciéndolo en irrisión y desprecio de la Sagrada Persona de S. Majestad". Gafarot, $\mathrm{AC} 42-6$ (3), fol. $27 \mathrm{r}$. 
ciudad catalana la relación 'adúltera se vistió de todos los pormenores. La manceba era nada menos que doña Josefa, marquesa de Esquilache; el monarca "la visitaba de rebozo y disfrazado, haciendo de ella según su gusto y licenciosidad" ${ }^{98}$. La pensión concedida al marido burlado $-\mathrm{y}$ siempre según las malas lenguas jesuíticas y terciarias - no fue sino un pago por los servicios que la esposa liviana había prestado al rey ${ }^{99}$. Más aún: los murmuradores añadieron que después del destierro del ministro caído, "S.M. quería renunciar al reino de España y retirarse a Nápoles con muchos millones para vivir con dicha señora; lo que dijo [el declarante] era voz común, pero que no hacía memoria de alguno en particular a quien poder citar ${ }^{100}$.

El lujo fantástico de detalles -relaciones madrileñas añadirian que los hijos de la marquesa, con espacios intérgenésicos demasiado cortos para la escasa potencia biológica del marido legítimo había que atribuírselos al rey enamorado- tiende a justificar la participación jesuítica en los motines: gracias a tales favores podía gobernar Esquilache tan despóticamente; y para evitar el escándalo, los organizadores se pusieron de acuerdo con la reina madre, Isabel de Farnesio, con los infantes incluso, convertidos asi en responsables egregios del motín ${ }^{101}$.

El modelo francés $y$, más cercano aún, el portugués está recompuesto. Si se dice que el rey de España está amancebado, cualquier cosa se puede y se debe temer de esos jesuitas que no dudaron en atentar contra la vida del monarca luso. Por de pronto, la nube de "sátiras y papeles infamatorios e injuriosos al Rey Fidelísimo, al ministro Carvalho y a todo el reino", que esparcieron los devotos de los jesuitas, se había repetido en el caso español. Había más, y ello preocupaba al orquestador de la "Pesquisa": en Gerona el canónigo Berga - cómo no- se encargó de convencer a todos los que quisieron escucharle (y fueron muchos) de lo fúnebre del pronóstico con que un jesuita explicó un cometa, o lo que fuere, "muy

98. Gafarot, AC 42-6 (3), fol. 27v; José del Vall, ibid., 13r; Juan Bono, ibid., 17r; Francisco Barris, ibid., 21v; Berga, AC 42-6 (2); 31v; Jaime Ferrer, ibid., $7 \mathrm{r}$.

99. Gafarot, ibid.

100. Jaime Ferrer, AC 42-6 (2), fol. $7 r$.

101. Berga, ibid., fol. $31 \mathrm{v}$. 
luminoso y encendido de la parte del Poniente, que se disipó a uno o dos truenos que vieron y oyeron muchos":

"que este fenómeno podía muy bien significar la muerte del Rey, porque como era regular que el Rey hubiese ido a Madrid por la fiesta del Corpus, acompañado de las guardias walonas, aquel pueblo, que no sufría burlas, bien podian haber muerto al Rey en el motin".

Ante la objeción -y hay que ver la finura con que se plantea la postura regalista y ultramontana- de que "estando dicho fenómeno algo inclinado a la parte del Norte podría más presto significar la muerte del papa, había respondido dicho jesuita: que no, sino que significaba la muerte del Rey" ${ }^{102}$.

Pero no se paran en barras -es decir en pronósticos- los jesuitas peligrosos y vitandos. Sus posturas teológicas regicidas son una espada que se cierne sobre la testa coronada de Carlos III como no espabile y tome las medidas urgentes decisivas. Buena prueba de ello es la "doctrina de los polvos". El abogado Jacinto Gafarot, responsable de la pesquisa laica gerundense, que sufre en el seno de su familia el drama de la división matrimonial por la terquedad jesuítica de "su parienta", pudo testificarlo. La tertulia comenta casualmente noticias de algún "Mercurio", en el que se narra la muerte repentina e ignorada de un transilvano. En seguida salta -en boca de un jesuita - la habilidad que tienen las mujeres para matar a los maridos a base de caricias y la ingestión de unos polvos mortíferos de acción lenta, pero inexorable. El abogado, que se siente aludido por las relaciones tirantes entre su esposa y él, se espanta. No tarda en recordarse el énfasis que miembros de la Compañía han puesto en airear que las enfermedades de doña Bárbara de Braganza y don Fernando VI fueron evidentemente un castigo del cielo por haber alejado al P. Rávago -es decir, a los jesuitas- del confesonario regio. Llega un lego -dominico, cómo no- de Italia, vía Francia, y sorprende al auditorio con la noticia de que en los mesones en que ha posado en el reino vecino cunde la

102. Berga, AC 42-6 (2), fol. 34v-36r. Esta curiosa acusación orquestada por el canónigo tuvo fortuna, y aparece en casi todos los testigos con Ieves variantes: Jerónimo Puig, ibid., fol. 9v; Mariano Sadurní, ibid., 15v; con idénticas palabras, Martín Rich, ibid., 16v, que indica el origen de todo; Narciso Farró, ibid., 18v; Fracisco Cors, ibid., 25v. Francisco Befarás, AC 42-6 (3), fol. $6 \mathrm{r}-\mathrm{v}$. $\mathrm{Y}$ en Barcelona, Abbach, AC 43-3, fol. $24 \mathrm{r}$; Isidoro Riera, ibid., 78v. 
convicción de que ambos consortes reales "habian muerto de veneno jesuítico".

La conclusión fluye espontánea de la pluma del amigo de Gafarot.

"Con esta especie, y haber leído contestada la misma en el libro intitulado Lupi smascherati ${ }^{103}$, extrañé menos que dichos jesuitas se esforzasen en seducir a los españoles que habian sido castigo del cielo aquella muerte, o muertes, que ellos habían causado practicando aquella maldita doctrina de los polvos que hacian efecto lento" 104.

Y la conclusión más general tiene que deducirla el rey por sí mismo: de no deshacerse de esta jauría sanguinaria, muy bien puede temer no le suceda algo parecido a lo ocurrido con su hermano y cuñada regios. De hecho el proceso contra el P. Calatayud, la persecución a que se sometieron sus escritos, obedecieron a la denuncia que un fraile de Madrid, que lo había oído de otro, hizo de la tertulia que el citado jesuita presidió en Pamplona (donde no pudo estar durante todo aquel año) para planear el asesinato del monarca ${ }^{105}$.

\section{Cuestiones frailunas}

El subfondo de la "Pesquisa" confirma algo que no necesita confirmaciones: la violenta lucha que se viene desarrollando en España desde antes entre dos frentes clericales hostiles y que toca su climax decisivo en los meses nerviosos que siguen a los motines; en realidad se trata del enfrentamiento de casi todas las órdenes religiosas (con sus clientelas), adunadas contra los jesuitas (y sus apasionados), cuyo declive se acelera vertiginosamente desde la caída del P. Rávago, desamparado ya del apoyo de Ensenada, y que explica que los rumores esparcidos durante los tumultos en pro del retorno del intrigante y eficaz ministro se convirtiesen en arma vuel-

103. Sobre la posible paternidad de esta obra, "Lobos desenmascarados", cfr. M. Danvila, o.c., III, p. 78.

104. Berga, AC 42-6 (2), fol. $36 \mathrm{v}-37 \mathrm{r}$; Gafarot, AC $42-6$ (3), fol. $26 \mathrm{v}-$ 27r. Se hacen eco: Jerónimo Puig, AC 42-6 (2), fol. 11r; José del Valle, AC 42-6 (3), fol $13 r$.

105. Naturalmente, el P. Calatayud no pudo estar en Pamplona durante el año de marras. El documento, cfr. en AGS, Gracia y Justica, Leg. 1.009 ; la exculpación en M. Danvila, o. c. III, p. 33. 
ta contra la Compañía, esperanzada en recobrar el poder perdido (según los murmuradores y algunas probabilidades) ${ }^{106}$.

Por una de tantas contradicciones como se registran en la historia de la oposición política dieciochesca, no demasiado conocida ${ }^{107}$, la Compañía ha cambiado sus actitudes radicalmente en el corto espacio de diez años: del Rávago ultrarregalista ${ }^{108}$ se ha pasado a posturas más genuinas y constantes de ultramontanismo. $Y$, por el contrario, el resto clerical, por urgencias antijesuíticas, en los meses de la pesquisa aparece como el mejor aliado del equipo reformador y "jansenista". Paradójicamente (y se les echará en cara como argumento de su participación en los motines, de sus predisposiciones antigubernamentales, antimonárquicas incluso), los jesuitas serán los portavoces casi solitarios de la defensa de privilegios clericales y de oposición a reformas que tienden a modificar el sistema de la Casa diezmera, de la percepción de Novales, en perjuicio del clero secular, y del proyecto de amortización -como hemos visto- en perjuicio del regular, cuya atonía momentánea sólo puede exp!icarse en fuerza de la animosidad contra la Compañía ${ }^{109}$.

El P. Isla; con su afortunado Fray Gerundio de Campazas, había contribuido a caldear el ambiente de hostilidades; no era difícil ver en su sátira la mofa lanzada contra la colectividad de los frailes. Los "gerundios" respondieron con todos los medios a su alcance, $y$, apoyados en el gobierno, conseguirían el triunfo definitivo.

Aunque el resultado fuera distinto, la significación del caso $\mathrm{Pa-}$

106. La conexión Ensenada-jesuitas, esgrimida como acusación fundamental de la oposición jesuítica al gobierno y de su intento de golpe de gobierno en beneficio de alguien que les fuese menos hostil; cfr. Raimundo de Irabién, AC 43-3, fol. 86v. (Los jesuitas comentaban ante su caída (la de Ensenada), "que dicha noticia era más sensible que las antecedentes del tumulto"). Pablo Bordius, ibid., 98v. Berga, AC 42-6 (2), fol. 32v.

107. Cfr. La síntesis de esta historia en C. E. Corona, "Sobre el tránsito del absolutismo al liberalismo", ya cit.

108. Bien estudiado el problema, centrado en Rávago pero con ampliación a otros tiempos, en la Introducción que Carlos Pereyra antepone a la edición de las Cartas del P. Rávago realizada por C. Pérez Bustamante, Madrid, s.f.

109. Y esta oposición contra lọs atentađos a derechos diezmeros, novales y amortizadores se les echa en cara a los jesuitas por los propios afectados. Jaime Ferrer, AC 42-6 (2), fol. 7r; Jerónimo Puig, ibid., 10v; Mariano Sadurní, ibid., 14.r; Berga, ibid., 33r, que transmite la oposición jesuítica a las nuevas contribuciones de Indias que forzarian los levantamientos de Quito de aquel mismo año y que están a la espera de ser estudiados. 
lafox fue idéntica. En realidad en 1766 se habia llegado a una situación bastante cómica en un proceso de dos más manipulados que registra la hagiografía frustrada: los defensores ocasionales del regalismo esgrimen todos los recursos posibles por lograr la beatificación del Venerable que, tiempos atrás, se permitió el lujo de denostar - no con excesiva acritud- a la Compañia; los ultramontanos jesuitas se empeñaron en una batalla campal para impedir el proceso. Curiosamente, los gobernantes "jansenistas" apoyaron denodadamente la causa del obispo de Osma.

$Y$ como es natural, en esta lucha clerical, los pesquisados sacaron a relucir las invectivas jesuíticas contra Palafox como signo de su postura antigubernamental. Parece que por Gerona "los Padres y sus devotos" se ensañaban contra el antiguo rival. El Hermano Baldo divulgaba en la plaza, al enterarse de la posible aprobación de los escritos del Venerable: "A ver; cómo pondrán (o también, pueden poner) un demonio en los altares". Años antes el P. Codroniu comenta en Olot ante la concurrencia: "que era imposible que el Sr. Palafox estuviese en carrera de salvación, porque había infamado a la Compañía, y ni en vida ni en muerte había retractado las infamias". O recitaban décimas denigrantes y tan duras como la prohibida por el Santo Oficio, ante los visos del proceso viable:

"¿Qué es el papa? - Un fiero hereje. ¿Y el rey Carlos? -Fragmasón",

y la insultante y alusiva a los orígenes espúreos del prelado ${ }^{110}$.

La constante que envuelve todo en un fondo doctrinal es la oposición de los sistemas tomista ("la sana doctrina") y suarista

110. Berga, AC 42-6 (2), fol. 46r-v; Jerónimo Puig, ibid., 10v; Francisco Cors. ibid., 25r-v; Gafarot, 42-6 (3), fol. 28r. El P. Jaime Ferrer, Mercedario jubilado, logró hacerse con la Décima que juega al mismo tiempo con el estribillo del venerable Palafox ("tanto más cuanto") y con sus orígenes (y es sólo una muestra de la enorme masa satírica que pululó desde antes acerca de este asunto de la beatificación):

"De repente, y mal cuajado,

te formó una trajalada;

en obra tan desdichada

no pudo ser de pensado.

Por un doblón y un pecado

tú al mundo venido has,

y vendiéndonos estás.

¿Qué vales? - "Tanto más cuanto".

Yo no sé que valgas tanto,

AC 42-6 (2) 8r. eso costaste y no más": 
("molinismo") de pensamiento y de enseñanza, hasta el punto de que se llegó a identificar al "tomista" con el regalista, o con el contrario a la Compañia, por una ampliación vulgarizada de la Escuela. En la Sala especial del Consejo de Castilla el apelativo sirvió como garantía de quienes se consideraban como enemigos irreconciliables de los jesuitas y cuyo voto se tendría casi asegurado a la hora decisiva. Algo similar sucede en la "Pesquisa", que respira tomismo por los cuatro costados y en la que se parte de la identificación de suarismo y malhab!antes contra el gobierno: "Vea V. M. -repetía Berga a cuantos le salían al paso- cómo los de la "sana doctrina" no hablan tan infamante, y con esto conocerá $V$. M. en qué fragua se van forjando tan indignas proposiciones" [contra el gobierno] ${ }^{111}$.

Hoy resulta difícil explicarnos la pasión derramada en cuestiones similares; mas para los acusadores había cierta conexión lógica entre enemigos del tomismo y oposición al gobierno, por la sencilla razón de que los jesuitas y apasionados se permitían amena. zar al rey por su pretensión de sancionar como única la "sana doctrina". Las denuncias coinciden en relatar que jesuitas graves divulgaban dichos como "que si el rey y su gobierno jansenista intentaban establecer la "doctrina sana", vería España grandes estragos" 112 .

Este odio de escuela con sus derivaciones políticas en estos meses agitados se manifiesta con toda su ridícula crudeza en el episodio de "El Farol". "El Farol" era el nombre de las tertulias que se tenían en el colegio jesuita de Belén "después del toque de oraciones". Y "El Farol", casi sin excepción, merodea por todas las declaraciones barcelonesas que lo presentan como antro casi de conspiración antigubernamental. La acusación va fraguando: "en "El Fa-

111. Mariano Sadurní, AC 42-6 (2), fol. 14v; Berga, ibid., 32r: "Yo varias veces hice advertir a algunos de mis amigos que observasen que los que hablaban con tal libertad eran sólo los secuaces y fieles defensores de los jesuitas, y no observé nunca que ninguno de los de sana doctrina hablase con tanto desahogo; antes bien, oi admirar a algunos la ceguedad y falta de juicio con que hablaban dichos sectarios de los jesuitas. Por lo que me confirmé más, y se lo confirmaron otros conmigo, de que tales infames papeles y voces venían todas dirigidas de la canal y fragua jesuítica".

112. Domingo Borja, OP, AC 43-3, fol. 72r; Juan Abbach, ibid., 4v; Jaime Senties, OP, ibid., 73v; Isidoro Riera, OSB, ibid., 79v; Domingo Fuster, ibid., 80r; José Vasiana, Pbro. ibid., 94v; Bernardo Vilaseca, ibid., 109r; Antonio Singla, estudiante de moral y sacristán de Santa Teresa, denuncia a un desconocido, del que sólo sabe que es "finisimo suarista", por haber celebrado la misa "contra persecutores Ecclesiae", ibid., 110r. 
rol" todo era hablar contra el gobierno y contra las religiones"; "se habla muy mal del gobierno"; "se habla con libertad contra el gobierno". Hasta Jerónimo Capmany, de los más ecuánimes, afirma que "se habla mal contra el gobierno y no es bueno lo que allí se habla". Lo realmente interesante es que ninguno de los testigos ha asistido a las reuniones y que todos ellos hablan por datos de tercera o cuarta mano, pues remiten a quienes lo oyeron de otros que decían haberlo oído a un contertulio esporádico que jamás quiso volver por alli ${ }^{113}$.

Hasta que, por fin, se rompe el "suspense" mantenido en torno a "El Farol" y aparece la fuente originaria: el que participó en la junta y no quiso volver era un pobre cura, conducido a "El Farol" casi a la fuerza por un "muy afecto y ciegamente apasionado" de los jesuitas, "con el fin de ganarlo a su partido". En el colegio se dio cuenta de que los tertulianos eran "padres jeuitas y eclesiásticos suaristas" de la ciudad. El incauto sacerdote quedó horrorizado, y cuando otro día el enlace le invitó de nuevo: "vamos a la Rambla", el declarante le contestó: "nunca más, no hables de eso", mientras se encargaba de comunicar a otras personas "que más quisiera estar en lo profundo del infierno que en aquella junta en la que había estado muy confuso y atónito".

Pero, en definitiva, ¿de qué se hablaba en la infernal reunión nocturna? El escandalizado asistente rompe con la mayor tranquilidad la expectación:

"El fin a que allí se congregaban era para hablar no bien de algunos sujetos, y especialmente de los que siguen la escuela tomista. Que dicha noche en que concurrió el declarante a dicha junta se habló primeramente de la Gaceta, que después se empezó a hablar mal de la escuela tomistica, diciendo uno que todos los tomistas eran unos ignorantes, poco civiles e intratables; otro que jamás queria ya tratar con ellos; otro que tenía odio formal a los tomistas; $y$ otros diferentes $y$ varias expresiones de que ahora no se acuerda" 114 .

Nada, en conclusión, contra el gobierno. Pero el episodio es elocuente para contrastar la deformación de una noticia "de escuela" y la politización que sufre a través de los testigos de la "Pesqui-

113. Juan Abbach; AC 43-3, fol. 23r; Angel Molas, ibid., 70r; Domingo Borja, ibid., fol. 72v; Jaime Senties, ibid., 73v; Tomás Piferrer, ibid., 76v; Jerónimo Capmany, ibid., 83r; Juan Borrás, ibid., 103v; Bernardo Vilaseca, ibid., 108v.

114. Joaquín Santacreu, AC 43-3, fol. 114r-v. 
sa", testigos férreamente tomistas: dominicos, canónigos, beneficiados, curas; o franciscanos, carmelitas, benedictinos, con tradiciones filosófico-teológicas ajenas al tomismo, pero asociados en esta circunstancia contra los "suaristas".

\section{Conclusión}

Se habrá podido observar: las acusaciones -entre pintorescas y formales- de la "Pesquisa" no aclaran el presunto protagonismo de los jesuitas en los motines (principalmente en el de Madrid) de 1766. Creer que los tumultos estuvieron orquestados por la Compañia, en cuanto colectividad, y sólo por ella, sería tan simple como achacarlos a la masonería inoperante, a un movimiento puramente espontáneo de un pueblo que quiere capas largas y sombreros gachos, o, sin más, a una crisis clásica de subsistencias -que está por matizar en cuanto a Madrid se refiere-, abocada a la inexorable lucha de frentes clasistas.

No obstante, las convicciones de que se parte y las claridades a que aboca están diciendo que, al menos para sectores amplios y sensibilizados - nunca desinteresados- era posible entonces la idea de que el motín de Madrid fuese dirigido por privilegiados, con un claro programa político, que coincide con los intereses del "Partido Españolista", al acecho de cualquier circunstancia propiciadora del retorno al poder de los aristócratas. Indudablemente, la primavera de 1766 vio coincidir ese cúmulo de resortes repetido en otros momentos conocidos del siglo XVIII español: cosechas deficitarias, importaciones masivas de trigos sicilianos, libertad de comercio de granos, alza de precios, actuación de la Junta de abastos, reforma del "traje nacional", resquemores de aristócratas y privilegiados por intentos fiscales y amortizadores, política eclesiástica de Roda, ministros extranjeros que calientan la explosiva xenofobia, acumulación de marginados en la villa, etc., etc. La conexión entre reivindicaciones de privilegiados y los motivos populares - conexión no tan escandalizante como a alguna tendencia historiográfica le resulta - se realizó a base de sátiras, panfletos, contra-bandos, reuniones, campañas de opinión, cuyo resultado alumbran con demasiada evidencia tanto la "Pesquisa" como otras fuentes ajenas, cuya importancia no sería honrado ignorar.

Los resultados finales son bien conocidos. Cayó Esquilache y siguió el otro italiano Grimaldi al frente de los asuntos de Estado; 
cayó el Gobernador de Castilla, y apareció al frente del Consejo un militar "Español", Aranda. El rey anuló las concesiones otorgadas en el fragor del motín y del miedo: el pan siguió costando cada vez más caro, las capas se cortaron, el sombrero gacho volvió a levantarse, Aranda se entregó a convenientes alardes demagógicos, y todo siguió igual prácticamente; es decir, las reformas siguieron su camino incontenible. Hasta que, de golpe para algunos, como previsible para los enterados de un proceso ya patente, la media victoria de los "Castizos" se vio afectada por la revancha que súpuso el alejamiento de los jesuitas, aliados de consideración en aquella circunstancia.

Y ésta fue la consecuencia más trascendente del motín de Madrid. La "Pesquisa" se empeña en enlazar ambos sucesos en una relación de causalidad. Tiene el valor de revelarnos casi todas las razones que S.M. C. se guardó en su real pecho, que ya habían sido manifestadas en parte por Roda en confidencia a Nápoles, y que se hallan sistematizadas en el ignorado "Dictamen" de Campomanes. Sin embargo, las imputaciones achacadas a los jesuitas no parecen justificar una medida radical, por más que el más hostil de los declarantes pidiese la expulsión, admirado de que aún "pudiesen subsistir en el mundo unos hombres tan turbulentos y sanguinarios, sino para que o se corrigiesen o sirviesen de ejercicio a los buenos y timoratos, como lo dice de los malos San Agustín" ${ }^{115}$.

No fue, por tanto, la expulsión el fruto de una conspiración masónica ni efecto de sectarismos librepensadores, a pesar de Gutiérrez de la Huerta, de don Marcelino Menéndez y Pelayo, de García Villoslada, etc. Se trató, sencillamente, de una formidable operación política, con escasas o nulas connotaciones religiosas y con muchos intereses gubernamentales, sociales y hasta económicos: de por medio. Los jesuitas, a aquellas alturas, se habían tornado en los portavoces, quizá inconscientes, de antirreformismos y en bastión demasiado fuerte -en apariencia- del heterogéneo "Partido aristocrático", que no puede coincidir con prácticas del gobierno que le aleja de un poder que efectivamente se detenta por extranjeros odiados o por "golillas" irrespetuosos, y de todas formas comprometidos en un Despotismo que no rimaba con tradiciones cordiales y provechosas a la aristocracia.

115. Francisco Berga, AC 52-6 (2), fol. $34 \mathrm{v}$. 
La habilidad de los conductores de la operación consistió en aislar estas fuerzas, en privar a los jesuitas del recurso a la defensa y en impedir la movilización de sus poderes multiformes: aristocracia (el $80 \%$ de los miembros de los Consejos, según mediciones provisionales de Olaechea, descansa sobre los co'egiales), apasionados, enseñanza, ejercicios, predicación, confesonario, dinero. Cuando posiblemente hubieran podido reaccionar, ya estaba consumado el proceso de su extrañamiento, forjado también a fuerza de imprudencias y de seguridades que les acarrearon la hostilidad de buena parte del clero secular y de casi todo el regular. Miguélez, polémico lo que se quiera, pero con atisbos de agudeza, materializa esta soledad con palabras exactas: "Tan ufanos y llenos de sí mismos se hallaban algunos jesuitas, que a pesar de vivir en aquellos tiempos calamitosos viendo encima el nublado que les amenazaba, en vez de hacerse pacíficos con la persecución y unirse a las demás corporaciones religiosas contra el común enemigo, fomentaron de nuevo la guerra, harto recrudecida, con las deplorables cuestiones escolásticas" ${ }^{116}$.

$Y$ estas cuestiones escolásticas no se quedaban reducidas al ámbito de bizantinismos estériles. Viejas doctrinas regicidas probabilistas, ultramontanismos fáciles, su dependencia del papa en momentos de regalismo y despotismo exarcebados, reacciones lógicas ante el temor de que en España sucediera lo mismo que había acontecido en Portugal y en Francia -y en 1766 los jesuitas ya lo sabían ${ }^{117}$-, todo se aprovechó para presentarlos al monarca como elementos de un todo incompatible con una línea política, inexorable y bien definida, no dispuesta a admitir oposiciones. En realidad, las acusaciones incontables de la "Pesquisa" (se les tacha de anglófilos - contra el Pacto sagrado de Familia - y hasta de haber consumado gigantescas fugas de "divisas", a más de sus críticas contra el gobierno, contra el mismo monarca, de estar dispuestos a utilizar los mortíferos polvos) tienden a potenciar, aunque sea de forma caricaturesca, los riesgos de un "cuerpo tan peligroso" para la monarquía absoluta de Carlos III. La hipótesis de trabajo de Corona se convierte, de esta suerte, en tesis fecunda y luminosa.

116. M. F. MIGUÉLEZ, Jansenismo y Regalismo en España, p. 306.

117. Abundantes datos al respecto en los trabajos y obras citados de R. Olaechea. 
Después, el frío y punzante estilo de Campomanes sabría conectar la débil argumentación con motivos más acuciantes, que hay que saber situar en el clima de los gobiernos de aquella Europa católica. A Su Majestad Católica — presa de pánico todavía por el eco de los motines- no le quedaba otra alternativa ante el contundente pedimento de su Fiscal:

\begin{abstract}
"En estos términos, resultando de todo ser los jesuitas en España e Indias el fomento y el centro de la disensión y del desafecto a la quietud, entiende el fiscal que ha llegado el punto de haber llenado la Compañía en España y en las Indias la medida del escándalo en punto de su predicación, de su enseñanza y de su infidelidad, y ser indispensablemente necesario para là seguridad de la sagrada persona de $\mathbf{S}$. M. y del reino entero que la soberanía use de su potestad económica, extrañando del reino a los jesuitas profesos y a los novicios que quieran permanecer en la Compañía; ocupándoseles las temporalidades, como extraños de él; no permitiendo que en estos dominios ni en los de las Indias se vuelvan a establecer en comunidad ni en particular con ningún pretexto, haciendo Su Majestad esta declaración a imitación de otros soberanos, como Rey que no reconoce superior en lo temporal y que usa de esta económica providencia para seguridad de su persona real y de la de su augusta familia y de sus dominios y por beneficio de la misma religión y pureza de las costumbres; haciendo cerrar desde luego todas sus casas y escuelas, y que no se enseñe más su doctrina, para evitar que no se dé ocasión con ella a nuevos escándalos en estos dominios" 118.
\end{abstract}

Aranda, por fin, el hombre del "Partido Castizo" que sobrevive, apenas si trascenderá de un papel de símbolo y de cobertera tranquilizadora de un programa en el que no tendrá brillante intervención. Mediatizado por Roda y Campomanes, debilitado por la movilidad de otros "castizos" (como el del sector de Alba) más agudos, cuando quiera actuar se encontrará con el dorado exilio de París, contemplando entre intrigas con el "Cuarto del Príncipe" el otro fracaso de 1776, cuando se asista a otro episodio más significativo, de un ciclo por otra parte tan repetido a lo largo de todo el siglo XVIII.

\title{
Teófanes Egido
}

Universidad de Valladolid. - Departamento de Historia Moderna.

118. Dictamen del Fiscal don Pedro Rodriguez Campomanes, 31 diciembre, 1766. AC 45-4, fol. 170r-v. 